\title{
Survival, growth and photochemical efficiency of silver fir seedlings produced with different technologies
}

Piotr Robakowski ( $\square$ piotr.robakowski@up.poznan.pl )

Poznan University of Life Sciences https://orcid.org/0000-0001-5564-7360

Tomasz Pietrzak

Poznan University of Life Sciences

Wojciech Kowalkowski

Poznan University of Life Sciences

Grzegorz Małecki

Poznan University of Life Sciences

\section{Research Article}

Keywords: Abies alba, chlorophyll a fluorescence, forest nursery, growth, photoinhibition

Posted Date: February 3rd, 2021

DOl: https://doi.org/10.21203/rs.3.rs-170498/v1

License: (a) (i) This work is licensed under a Creative Commons Attribution 4.0 International License.

Read Full License 
1 Survival, growth and photochemical efficiency of silver fir seedlings produced with

2 different technologies

3

$4 \quad$ *Piotr Robakowski, Tomasz Pietrzak, Wojciech Kowalkowski, Grzegorz Małecki

5

6

7 Poznan University of Life Sciences, Faculty of Forestry, Department of Silviculture, Wojska

8 Polskiego 71E, PL 60 - 625 Poznań, Poland, phone: +48 6184877 38;

$9 \quad$ * piotr.robakowski@up.poznan.pl

10

11

12

13 * Author for correspondence

14

*ORCID: 0000-0001-5564-7360

15

16

17

18

19

20

21

22

23

24 
Forest tree seedling production technologies impact reforestation success determined with survival and quality of seedlings. Five Abies alba seedling production technologies were tested: (1) bare-root seedling, three years in the open (3/0); (2) bare-root seedling, two years under a shading net (40\% of full light), a year in the open $(2 / \mathrm{g}) ;(3)$ ball root seedling, two years under a shading net $(40 \%)$, a year in the open $(2 / \mathrm{K}) ;(4)$ bare-root seedling grown in an opening in a Norway spruce stand (3/Pic); (5) bare-root seedling, three years under Scots pine canopy (3/Pin). Silver fir seedlings acclimatized their growth rates to the common growing environment in relation to the seedling production technology used in the nurseries. The height and diameter at root collar were positively correlated with survival. The 3/Pic seedlings manifested the lowest survival and were lower than other seedlings in terms of height and photochemical efficiency. The needle photochemistry of seedlings growing two years in plantation was determined by their earlier acclimation to the nursery light conditions. The production technology determined the ability of $A$. alba seedlings to acclimatize to the natural environment. Ball root seedlings grown two years in shade and a year in the open $(2 / \mathrm{K})$ acclimatized better to the full light environment compared with bare-root seedlings produced in canopy shade, and they are likely more suitable to be planted after clearcutting. 
Reforestation success can be increased by enhancement of seedling tolerance to biotic and abiotic stresses, using an appropriate seedling production technology that is concomitant with the species' ecological requirements (Brang et al. 2014; Ruotsalainen 2014; Batavia and Nelson 2016). Seedlings transferred from a nursery to a forest site are often threatened by abrupt changes in light environment, extreme air temperatures, drought and/or deficit of nutrients, and by different biotic stressors (Rietveld 1989; Grossnickle 2005).

While methods of seedlings cultivation in forest nurseries are of pivotal importance for reforestation success, many other factors influence seedling performance after transplantation: provenance, climatological conditions, planting site, time and method of transplanting, root growth rates, and length of storage (South and Mexal 1984; Grossnickle 1988). Seedlings grown in a forest nursery acclimatize to the nursery climate and soil conditions. This initial acclimatization impacts growth and physiological performance of seedlings after being transferred from a nursery to a plantation, but the mechanisms of these processes and their relation with the seedling production technology have not been fully elucidated (Burdett 1990). This confrontation with the natural environmental conditions is usually stressful for seedlings that have been irrigated and fertilized in the nursery. To reduce transplant stress and to increase reforestation success, seedlings can be grown in the nursery in the conditions as similar as possible to those in which they will be planted (Kozlowsky and Pallardy 2002). According to the Target Plant Concept, more emphasis should be placed on how seedlings perform on the outplanting site rather than on nursery performance. The information from post-planting monitoring about limiting factors of growth, genetic criteria, stock type and outplanting techniques can be used to improve subsequent plant materials (Dumroese et al. 2016).

Reforestation success can be achieved by production of seedlings using pro-ecological methods while keeping in mind their species-specific ecological requirements, e.g. shadetolerant species should be grown under the shade of a forest tree canopy or shading net (Barzdajn 2000; Puértolas et al. 2009). To ensure suitable water conditions and mycorrhizal associations, seedlings are produced with covered roots in ballots filled with forest soil and peat without fertilization or pesticides. Pro-ecological silver fir (Abies alba Mill.) seedling production technology has been successfully applied in a programme of silver fir restoration in the Sudety Mts., SW Poland that has been conducted since 1999 (Barzdajn 2000). Overall, the understanding of ecophysiological mechanisms associated with resistance to planting 
stress and early establishment in forests has been shown to improve reforestation success with different tree species, including silver fir (Burdett 1990; Margolis and Brand 1990;

Robakowski et al. 2004; Oliet and Jacobs 2012).

In Poland, seedlings of shade-tolerant species such as Abies alba, Fagus sylvatica L. or Picea abies Karst. are occasionally produced under a canopy of mature forest trees, in managed forest conditions. For shade-tolerant species, which are more sensitive to high light and high temperature amplitudes compared with shade-intolerant species, a growth environment under a canopy of mature forest trees is more suitable than typical nurseries in open areas. On the other hand, the environment under a canopy of trees can be highly specific and heterogeneous depending on the main species in the canopy. Each monospecific or mixed stand forms a unique environment with specific microclimate, soil conditions and species composition (Hobbie et al. 2007; Mueller et al. 2015). For Quercus petraea (Matt.) Liebl., Fagus sylvatica L. and Acer pseudoplatanus L. grown six years under a Norway spruce canopy, however, growth parameters were not correlated to the light environment (Kazda et al. 2004).

Seedlings transferred from the undercanopy or from a shading tent to be planted in the open conditions will be more threatened by different stressors, especially photoinhibition compared with seedlings acclimated to full light in a nursery in open areas (Mohammed and Parker 1999; Naramoto et al. 2006). Excessive light energy can damage the leaf photosynthetic machinery, leading to a substantial decrease in maximum quantum yield of PS II photochemistry $\left(\mathrm{F}_{\mathrm{v}} / \mathrm{F}_{\mathrm{m}}\right)$ and quantum yield of PS II in light $\left(\Phi_{\mathrm{PSII}}\right)$ which are related to seedling potential and effective photosynthetic performance. A reduction of $F_{v} / F_{m}<0.8$ is regarded as a good indicator of photoinhibition, which decreases photosynthetic electron transfer rates and subsequently photosynthetic performance and growth of plants (Baker 2008; Krause et al. 2012; Ruban 2015; Kromdijk et al. 2016). Photoinhibition can be induced by high or low temperatures occurring together with high light. A reduction of $F_{v} / F_{m}$ also occurs under drought, nutrient deficit, high salinity and other stressors (reviewed by Kalaji et al. 2016). In evergreen conifers, in winter, a transient decrease in $F_{v} / F_{m}$ plays a photoprotective role under high light and low temperatures and can be regarded as an adaptive feature to photoinhibitory conditions (Adams III and Demming-Adams 1994; Adams et al. 2004; Robakowski 2005; Yamazaki et al. 2007; Ye et al. 2012).

Silver fir is an important forest tree for montane forest diversity and wood production. It is one of the most shade-tolerant European trees and is able to survive even under decades 
of deep shade but responds rapidly to a clearing in the canopy (Brzeziecki and Kienast 1994; Dobrowolska et al. 2017). Survival and growth during the first two years require a minimum of around 5\% of incident irradiance. Five-year-old saplings may be found down to $8 \%$ of full light in natural stands, but under artificial shading and optimal watering and fertilization seedlings grew best at $18 \%$ and total biomass increases up to $100 \%$ in full light with high mass allocation to roots (Robakowski et al. 2003). Silver fir grows in a climate characterized by high air humidity and low temperature amplitudes. A mean annual rainfall of $700 \mathrm{~mm}$ limits its natural range in the north. The best growth occurs where mean annual rainfall exceeds $1500 \mathrm{~mm}$ and the mean annual temperature is about $9{ }^{\circ} \mathrm{C}$ (CABI 2005). A. alba does not tolerate minimum temperatures below -20 to $-25^{\circ} \mathrm{C}$. Low temperatures in winter, spring frosts and water deficits are the main factors that determine the northern and eastern limits of its natural range. Such conditions occur in mountains and rarely in uplands of Central, Southern and Western Europe. In Poland, silver fir grows naturally in mountains and uplands, from 500 to 1100 m a.s.l. (Gostyńska-Jakuszewska 1972).

In European forests, silver fir dieback has been periodically observed since about 1500 (reviewed by Dobrowolska et al. 2017). Different reasons for the regression of silver fir have been implemented (Barzdajn 2000). The main aim of this project is to increase the silver fir 
152 find a silver fir seedling production technology that will be the most suitable for artificial fir regeneration and have the highest reforestation success in the given site conditions.

Bare-root seedlings are more sensitive to handling practices of lifting, storage, transport and planting, and these practices can negatively affect their first-year survival and height. Ball root seedlings can have a higher level of field survival, which is related, in part, to their greater drought tolerance potential, thereby overcoming planting stress. Once seedlings are established, bare-root and ball root seedlings have comparable field performance (Grossnickle and El-Kassaby 2015). Although different technologies of silver fir seedling production are applied in forest nurseries, there has not been evidence of how seedling production technology affects the ability of seedlings to acclimatize after being transferred from a nursery to a plantation. In the present study, we have compared five different technologies of silver fir seedling production when they are grown in plantation in an open area.

The choice of the most effective seedling production technology is necessary to improve cost-benefit outputs of silver fir restitution in the Sudety Mts. The seedling production technology linked with the Target Plant Concept is of great practical importance for producing and evaluating stock types, planting and coping with abiotic stressors, interacting with vegetation, and assuring sufficient survival in conditions that are not always consistent with silver fir ecological demands. We posited that seedlings that were grown with different technologies in nurseries and then planted in the open would not acclimatize to the new environment within two years after planting. The alternative hypothesis was that acclimatization of seedlings to the outplanting site conditions would override differences obtained from acclimatization to the nursery conditions.

The following hypotheses were tested: (1) Seedlings grown under the shade of the canopy will have lower growth rates and will be more sensitive to photoinhibition than seedlings produced in a nursery in open areas or grown two years under artificial shading and at least one year acclimated to full sunlight. (2) Bare-root seedlings will be characterized by lower growth and photosynthetic performance compared with ball root seedlings. The practical aim of our study was to indicate the most effective silver fir seedling production technology that would result in high growth dynamics, high photochemical performance and high reforestation success under the full light environment.

\section{Nursery phase}




\section{Material}

Cones were collected in the temporary seed stand of silver fir and seedlings were produced in the forest nurseries of Forest Division Międzylesie $\left(50.149444{ }^{\circ} \mathrm{N}, 16.666389\right.$ $\left.{ }^{\circ} \mathrm{E}\right)$ in the Sudety Mts., SW Poland (Table 1). The open nursery and shading tents were localized in Międzygórze $\left(50.230833^{\circ} \mathrm{N}, 16.766667^{\circ} \mathrm{E}\right)$, the nursery under the Pinus sylvestris canopy in Idzików ( $8 \mathrm{~km}$ from Międzygórze) and the nursery under the canopy of Picea abies close to Nowa Wieś ( $3 \mathrm{~km}$ from Międzygórze and $11 \mathrm{~km}$ from Idzików). In Międzygórze nursery, seeds of silver fir were sown by hand in broadcast seeding in the open and in a polyethylene tunnel. Before sowing the substrate in tents was dug, fertilized and limed. In the open nursery, soil was cultivated with a rototiller, fertilized, rolled and then seedbeds were prepared. In both nurseries under shelterwood soil was cultivated with the rototiller, raked and seedbeds were manually prepared. In tunnel, at the initial stage of development, seedlings were irrigated 2-3 times a day within 10 minutes, and later twice a day within 5 min. depending on substrate moisture. In the nursery under the Pinus sylvestris canopy, at the early stage of development seedlings were manually watered on several occasions. In the other nurseries seedlings were not irrigated. In all the nurseries seedlings were fertilized with Hydrocomplex $(12 \% \mathrm{~N}, 11 \% \mathrm{P}, 18 \% \mathrm{~K}, 2.7 \% \mathrm{Mg}$ and microelements, $200 \mathrm{~kg} \mathrm{ha}^{-1}$ ) and fungicides Topsin and Granuflo were applied. Weeding was done $3-4$ times in spring and in summer. In November 2014, in tunnel there were 510, in the open nursery 304, under the Pinus sylvestris canopy 105 and under the Picea abies canopy 118 seedlings $\mathrm{m}^{-2}$. In April 2016, seedlings grown in tunnel were transplanted into Kosterkiewicz' ballot filled with peat and compost (1:1). The Kosterkiewicz' ballot is made from a thick plastic film and it has the shape of cuboid $(5 / 5 / 17 \mathrm{~cm})$. Seedlings in Kosterkiewicz' ballots were irrigated in dry weather conditions twice a day within $10 \mathrm{~min}$. Prior to transplanting to the experimental plot, seedlings were grown under the nursery conditions for three years. Five seedling production technologies were applied (Table 1): (1) bare-root seedling, three years in the open nursery (3/0); (2) bare-root seedling, three years under the Pinus sylvestris canopy (canopy openness $30 \%$ ) (3/Pin); (3) bare-root seedling, three years in opening in a Norway spruce (Picea abies Karst.) stand (canopy openness 65\%) (3/Pic); (4) bare-root seedling, two years under a shading net (40\% of full sunlight), a year in the open (2/g); (5) ball-root seedling, two years under a shading net (40\%), a year in Kosterkiewicz' ballot in the open $(2 / \mathrm{K})$.

\section{Outplanting phase}


The experimental area is situated close to the village "Janowice Wielkie" $\left(50.8822^{\circ} \mathrm{N}\right.$,

$21915.9217^{\circ}$ E), Forest Division "Śnieżka”, in the Sudety Mts., in the massif "Rudawy

220 Janowickie", SW Poland. In 2016, a stand of Scots pine (Pinus sylvestris L.) with a Norway spruce (Picea abies Karst.) and birch (Betula pendula Roth.) admixture was clear-cut, wood was removed and a 1-ha study area was established and fenced to protect against browsing by ungulates. The topography of the study terrain is flat and the type of soil is acid brown. In the depth $5-10 \mathrm{~cm} \mathrm{pH}$ of soil was 4.5 , in $50 \mathrm{~cm} \mathrm{pH}$ was 4.2, and in $1 \mathrm{~m} \mathrm{pH}$ was 4.1. The climate is typical for submountainous elevations. The long-term mean annual temperature is $7{ }^{\circ} \mathrm{C}$. The mean temperature of the vegetative season is between $12-13{ }^{\circ} \mathrm{C}$. In January, February and March the mean 24-h temperature does not go below $-3{ }^{\circ} \mathrm{C}$. The annual precipitation is $742 \mathrm{~mm}$. The highest precipitation occurs in July $(142 \mathrm{~mm})$ and the lowest in January and September (33 mm).

Experimental design

In March 2017, the three-year-old seedlings were planted with a mattock in a 2-m grid (2500 seedlings per ha). The 1-ha open experimental plot was fenced to protect fir seedlings against browsing by ungulates. Seedlings were planted in a completely randomized block design with 5 blocks and within each block there were 5 seedling production technologies (Fig. 1). In each block 100 seedlings per seedling production technology were planted (5 blocks x 5 technologies $\times 100$ seedlings $=2500$ seedlings).

Climate conditions and soil moisture

Air temperature and air relative humidity were monitored using three Hobo Pro data loggers installed at $30 \mathrm{~cm}$ above ground (OnSet Computers, Pocasset, MA, USA).

240 Precipitation was measured with a pluviometer connected to an Em50 data logger (Decagon 241 Devices, Inc., Pullman, WA, USA). Volumetric soil moisture was continuously measured at 242 three soil depths: 15, 30 and $50 \mathrm{~cm}$ with 10HS soil moisture sensors (Decagon Devices, Inc.,

243 Pullman, WA, USA). The meteorological data and soil moisture were recorded every 20 mins 244 from April 2017 to October 2019.

\section{Methods}

246 Growth measurements and assessment of seedling survival 
In September 2017 and 2018, the height $(h)$ and diameter at root collar $(d)$ of all seedlings were measured. The degree of slenderness was calculated as the ratio $h / d$, which is an indicator of tolerance to damage by wind and snow. In September 2018, two years after planting, to assess seedling survival, the percentage of live seedlings per block by seedling production technology was calculated. At the same time, the number of seedlings with needle discolouration and/or root collar damage by insects was also noted. Discolouration was observed on current lateral shoots and less frequently on a leader shoot damaged by the late 254 frosts.

In August 2018, needles of the latest flush of growth were weighed, and their projected area was measured with a calibrated scanner (Epson, STD 4800) equipped with WinSeedle ${ }^{\mathrm{TM}}$ software (Regent Instruments, Inc., Canada). Then, needles were dried at $65^{\circ} \mathrm{C}$ for a week and dry mass weighed. Water content in needles was determined by subtracting needle dry mass from needle fresh mass, and these values were normalized by dry mass. Leaf mass-to-area ratio (LMA) was also calculated according to the equation: LMA $=$ Needles dry mass $(\mathrm{g}) /$ Exposable needles area $\left(\mathrm{m}^{2}\right)$.

Pulse-modulated chlorophyll $a$ fluorescence

At the beginning of September 2018, pulse-modulated chlorophyll $a$ fluorescence was measured using the Fluorescence Monitoring System (FMS 2, Hansatech, Norfolk, UK) operating in an online mode. Needle samples (3 needles per seedling) were collected from the last (upper) whorl from 5 seedlings per block and treatment. The fiber optic light tube encased in a light-tight chamber was inserted onto the leaf clip and the upper side of needles was exposed to modulated measuring light of $0.05 \mu \mathrm{mol} \mathrm{m}^{-2} \mathrm{~s}^{-1}$. After reading the minimum fluorescence yield $\mathrm{F}_{0}$, a saturating $0.7 \mathrm{~s}$ pulse of light $\left(\mathrm{PPF}=15.300 \mu \mathrm{mol} \mathrm{m} \mathrm{m}^{-2} \mathrm{~s}^{-1}\right)$ was delivered to measure maximum fluorescence yield $\left(\mathrm{F}_{\mathrm{m}}\right)$. The measurements were taken at ambient temperature, 20 to $23^{\circ} \mathrm{C}$, which was monitored during the fluorescence measurements using a thermocouple installed in the clip. Subsequently, needles in the clip were illuminated with actinic light of $350 \mu \mathrm{mol} \mathrm{m}^{-2} \mathrm{~s}^{-1}$ using an inbuilt halogen lamp until steady-state fluorescence $\left(\mathrm{F}_{\mathrm{s}}\right)$ was reached. Then, a $0.7 \mathrm{~s}$ saturating pulse was switched on and maximum light-adapted fluorescence $\left(\mathrm{F}_{\mathrm{m}}^{\prime}\right)$ determined. The quantum yield of PS II was calculated by FMS 2 software as: $\Phi_{\mathrm{PSII}}=\left(\mathrm{F}_{\mathrm{m}}^{\prime}-\mathrm{F}_{\mathrm{s}}\right) / \mathrm{F}_{\mathrm{m}}^{\prime}$ (Genty et al. 1989; Maxwell and Johnson 2000). 
The maximum quantum yield of PS II photochemistry $\left(F_{v} / F_{m}\right.$, where $F_{v}=F_{m}-F_{0}$ is variable fluorescence, $F_{m}$ is maximum fluorescence yield, and $F_{0}$ is minimum fluorescence yield) was monitored on 13 occasions in 2 blocks (blocks II and III, Fig. 1) from April 2018 to May 2019. The needles of 5 randomly selected seedlings per block and per treatment were collected from the top whorl of the seedling, wrapped in moist paper and enclosed in Eppendorf tubes. Prior to measurements, the needle samples were adapted to dark for 0.5 hours at ambient temperature and then arranged tightly and stuck on self-adhesive transparent tape and introduced into a clip to fill its entire aperture. Chlorophyll $a$ fluorescence was measured using the Plant Efficiency Analyser (PEA, Hansatech, Norfolk, UK). The time of the fluorescence measurement was $1 \mathrm{~s}$ and PPF (photosynthetic photons flux) of the continuous red light-inducing fluorescence kinetics in needles was $2800 \mu \mathrm{mol} \mathrm{m}^{-2} \mathrm{~s}^{-1}$.

A one-way ANOVA $(P \leq 0.05)$ with 5 levels (seedling production technologies) and 5 blocks was applied according to the following statistical model: $y_{i j}=\mu+A_{i}+R_{j}+e_{i j}$, where $y_{i j}$ - the observation, $\mu$ - the general mean value based on all observations, $A_{i}-$ the effect of $i^{\text {th }}$ seedling production technology $(i=1,2, \ldots, t), R_{j}$ - the effect of $j^{\text {th }}$ block $(j=1,2$, $\ldots, b)$, and $e_{i j}$ - the error, which is assumed to be independent and normally distributed with mean zero and constant variance. The mean values were calculated for each seedling production technology in each block and then the above model was used for height, diameter and survival of seedlings. The block effect on fluorescence data and LMA was not significant, thus the one-way ANOVA was applied following the model: $y_{i j}=\mu+A_{i}+e_{i j}$, where $y_{i j}$ represents the $j$-th observation $\left(j=1,2, \ldots, n_{\mathrm{i}}\right)$ on the $\mathrm{i}$-th treatment $(i=1,2, \ldots, k$ levels), $\mu$ is the common effect for the whole experiment, $A_{i}$ represents the $i$-th effect of seedling production technology, and $e_{i j}$ represents the random error present in the $j$-th observation on the $i$-th seedling production technology. Prior to the ANOVA, the normality and homogeneity of data were checked using Shapiro-Wilk's and Levene's tests, respectively. Data that did not fulfil the ANOVA conditions were log-transformed, and the percentage values of survival were transformed using the Bliss' function: $\arcsin \sqrt{\mathrm{p} / 100}$. When the effect of seedling production technology was significant, Duncan's a posteriori test was applied to compare the mean values ( $\alpha=0.05, \alpha-$ level of significance). 
310 The logistic model: $y=\frac{1}{1+e^{-\frac{x-a}{b}}}$ was fitted to the values of probability of survival and

311 diameter at root collar or height of seedlings ( $y$ - probability of survival; $x$ - diameter at root

312 collar or height of seedling; $a, b$ - fitted parameters). The values of Pearson's coefficients of

313 correlation $(r)$ between climatic parameters, soil volumetric water content and fluorescence

314 parameters were calculated.

\section{Results}

Meteorological parameters

Meteorological parameters were analysed from April 2018 to May 2019, the same period when chlorophyll $a$ fluorescence was monitored (Table 2). Monthly sums of photosynthetic photon flux density $\left(P P F D_{\text {sum }}\right)$ were highest in spring and summer 2018 and lowest in winter $2018 / 19$ (Table 2). Mean monthly temperature $\left(T_{\text {mean }}\right)$ varied from $-2.9^{\circ} \mathrm{C}$ in January 2019 to $19.4{ }^{\circ} \mathrm{C}$ in August 2018. The amplitudes between the maximum monthly temperature value $\left(T_{\max }\right)$ and minimum monthly temperature $\left(T_{\min }\right)$ were greatest in winter and spring 2019, but they were also high in spring and summer 2018. The mean monthly relative air humidity $\left(\mathrm{RH}_{\text {mean }}\right)$ did not decrease below $72 \%$, but the minimum monthly relative humidity $\left(R H_{\min }\right)$ decreased at times to $19 \%$ suggesting that air drought might affect plants in August and September 2018. Monthly sums of precipitation were 3-fold higher in May 2019 than in May 2018. Precipitation achieved the lowest values in August 2018 and November 2018 when the height growth of silver fir was finished (Table 2). Monthly mean volumetric soil water content at $15 \mathrm{~cm}(V W C)$ varied from approximately $21 \%$ (minimum $18 \%$ ) in August 2018 to $30 \%$ (maximum $31 \%$ ) in winter and spring 2019. At $50 \mathrm{~cm} \mathrm{VWC}$ varied slightly from 27 to $33 \%$.

Survival of seedlings

Survival was assessed in September 2018. The seedling production technologies can

334 be classified from the highest to the lowest survival of seedlings in the following order: $2 / \mathrm{K}>$ $2 / \mathrm{g}>3 / \mathrm{Pin}>3 / 0>3 / \mathrm{Pic}$. The highest percent of dead seedlings was in 3/Pic, and there were no significant differences among the other treatments in Duncan's test (Table 3). The percentage survival of silver fir seedlings was positively related to the mean values per block of $d$ and $h$, indicating that seedlings of a larger size manifested higher survival than small ones (Fig. 2a, b). The $h / d$ ratio (a degree of slenderness) was not related to survival $(r=0.032$, n.s.). Red or brown needles discolouration of lateral shoots of dead seedlings indicated 
341 damages by the late frosts. At root collar of dead and some live seedlings we observed

342 damages by Hylobius abietis L. Adult insects of these species were found in summer 2018.

343 Around $20 \%$ of seedlings were damaged by the late frosts and insects independently of the

344 seedling production technology.

345 Growth and leaf structure of seedlings

In September 2017 (year of transplanting) and 2018, the mean values of $d$ depended on the seedling production technology (Table 4, Fig. 3a). In 2017, the mean $d$ was highest in $2 / \mathrm{K}$ and $2 / \mathrm{g}$ (6.5 \pm 1.4 and $6.6 \pm 1.1 \mathrm{~mm}$, respectively), and did not differ among 3/Pin, 3/Pic and $3 / 0(\approx 5.4 \pm 1.1 \mathrm{~mm})$. A year later, $2 / \mathrm{K}$ and $2 / \mathrm{g}$ seedlings again had the highest mean $d$ (8.2 $\pm 1.8,7.8 \pm 1.6 \mathrm{~mm}$, respectively), but $2 / \mathrm{K}$ did not differ from $3 / \mathrm{Pin}$ and $2 / \mathrm{g}$, and the lowest mean $d$, in 2/Pic $(6.6 \pm 1.9 \mathrm{~mm})$ did not significantly differ from $3 / 0$. The differences in mean values of $h$ among the seedling production technologies were significant in 2018 (Table 4, Fig. $3 \mathrm{~b})$. The $2 / \mathrm{K}$ and $3 / \mathrm{Pin}$ seedlings showed the higher mean values of $h(241 \pm 72,225 \pm 77$ $\mathrm{mm}$, respectively) compared with 2/Pic (196 $\pm 63 \mathrm{~mm})$, and 2/g and 3/0 $(213 \pm 70,223 \pm 76 \mathrm{~mm}$, respectively) did not differ significantly from the other technologies. In 2017, there were significant differences in $h / d$ with the lowest value of this ratio in $2 / g(23 \pm 6)$, but in 2018 the differences in the $h / d$ ratio were not significant. When all treatments were pooled, in 2017 the mean $h / d=28 \pm 8$, and in 2018, $h / d=30 \pm 10$ (Table 4, Fig. 3c).

After two seasons of growing in the plantation, bare-root seedlings acclimated one $(2 / \mathrm{g})$ or three (3/0) years to full sunlight showed higher values of LMA $\left(175 \pm 7,175 \pm 5 \mathrm{~g} \mathrm{~m}^{-2}\right.$, respectively) than those acclimated to the environment created by the Scots pine $(159 \pm 4 \mathrm{~g}$ $\mathrm{m}^{-2}$ ) or Norway spruce $\left(162 \pm 4 \mathrm{~g} \mathrm{~m}^{-2}\right.$ ) stands (3/Pin, 3/Pic) and the root-ball seedlings $2 / \mathrm{K}$ $\left(160 \pm 5 \mathrm{~g} \mathrm{~m}^{-2}\right)\left(F_{4,96}=2.68, P=0.036\right)$ (Fig. 4).

Quantum yield of PS II photochemistry

At the beginning of August 2018, the treatments did not differ in $\mathrm{F}_{\mathrm{v}} / \mathrm{F}_{\mathrm{m}}(P=0.523)$.

The mean values of this parameter were approximately $10 \%$ lower than the optimum value = 0.84 (Björkman and Demmig 1987; Lüttge et al. 2003) independent of the seedling production technology. In contrast, $\Phi_{\text {PSII }}$ depended on the acclimation of seedlings to the growing conditions in nursery $\left(F_{4,84}=3.16, P=0.018\right)$. The mean value of $\Phi_{\text {PSII }}$ was higher in 
371 of $\Phi_{\text {PSII }}$ in $3 /$ Pic was lower than in $3 / 0(0.13 \pm 0.01)$. The $2 / \mathrm{K}$ seedlings did not differ from the others (0.12 \pm 0.01$)$ (Fig. 5).

373 Seasonal evolution of maximum quantum yield of PS II photochemistry performance. In April 2018, a year since the planting, the effect of the seedling production technology on $\mathrm{F}_{\mathrm{v}} / \mathrm{F}_{\mathrm{m}}$ was significant according to the one-way ANOVA $\left(F_{4,45}=4.81, P=\right.$ $0.003)$. The mean values of $\mathrm{F}_{\mathrm{v}} / \mathrm{F}_{\mathrm{m}}$ were higher in $3 / 0,2 / \mathrm{g}$ and $2 / \mathrm{K}(\approx 0.8)$ than in $3 / \mathrm{Pic}$ and 3/Pin (0.669 and 0.700) (Fig. 6a). In May 2019, 3/0 seedlings showed the lowest $F_{v} / F_{m}$. On all other occasions, there were no significant differences in $\mathrm{F}_{\mathrm{v}} / \mathrm{F}_{\mathrm{m}}$ among the seedling production technologies. The time-course of $\mathrm{F}_{\mathrm{v}} / \mathrm{F}_{\mathrm{m}}$ was driven by seasonal changes in air temperature and light. In May 2018, a remarkable decrease in $\mathrm{F}_{\mathrm{v}} / \mathrm{F}_{\mathrm{m}}$ up to $\approx 0.600$ was observed independently of the seedling production technology which was probably due to the late frosts. In June and July 2018 this index increased to 0.770 and then in August, under low $R H$ (Table 2), it diminished to $\approx 0.720$, and in September 0.660. In January, February and March 2019 it was in the range between 0.513 and 0.545 . The greatest decrease in $\mathrm{F}_{\mathrm{v}} / \mathrm{F}_{\mathrm{m}}$ of $55 \%$ was in $2 / \mathrm{g}$ in January 2019, but a recovery of $97 \%$ was also seen in these seedlings in May 2019. In April and May 2019, together with increasing air temperature, a partial recovery of $F_{v} / F_{m}$ was noticed. The lowest recovery of $F_{v} / F_{m}$ was recorded in 3/0 (0.68). $F_{0}$ did not differ among the seedling production technologies but varied seasonally. Low air temperatures increased $\mathrm{F}_{0}$, and higher temperatures, inversely (Table 5, Fig. 6b). $\mathrm{F}_{\mathrm{m}}$ varied seasonally and on two occasions significantly depended on the seedling production technology (Table 5, Fig. 6c). $\mathrm{F}_{\mathrm{v}} / \mathrm{F}_{\mathrm{m}}$ was positively correlated with $\Sigma \mathrm{PPFD}, T_{\text {mean }}, T_{\min }, T_{\max }$, in the window of 10 days before fluorescence measurements, and negatively with $R H_{\min }$, whereas $\mathrm{F}_{0}$ was negatively correlated with light and temperature. $\mathrm{F}_{\mathrm{v}} / \mathrm{F}_{\mathrm{m}}$ was negatively correlated with $\mathrm{F}_{0}$ (Table 5). Effects of climate conditions on seedling photosynthetic performance overrode effects of the seedling production technology.

\section{Discussion}

Survival, growth and leaf structure

The results supported the hypothesis that production technologies affected survival, growth and to a lesser extent the quantum yield of PS II efficiency of silver fir seedlings planted in clear cut plantations. There was evidence that survival of seedlings depended on 
402 their size: thicker and taller seedlings showed higher survival overall than those with smaller 403 dimensions. This is consistent with the results of Grossnickle and El-Kassaby (2015) that 404 showed that in many instances where plant competition is the main limiting site variable, 405 larger-sized bare-root and ball root stock types have the best chance for successful stand establishment. There has been evidence that root morphology and physiology influence survival and performance of seedlings in nursery and in outplanting conditions (Davis and Jacobs 2005). Proportion of root systems to shoots, root system area and length as well as root growth potential, carbohydrate content, nutrient and water storage in roots are tied with seedlings performance and can influence the speed with which seedlings overcome planting stress, thereby ensuring successful seedlings establishment (Grossnickle 2012). In our experiment, the distance between seedlings was $2 \mathrm{~m}$ and there was no strong competition with other plant species, thus this was not an important factor affecting growth and survival. We suspect that larger seedlings were more tolerant to the late frosts, having their growing point above the cold air lying on the ground in spring. Likely, they had stored more resources, which gave them an advantage over smaller seedlings under stressed conditions. The highest number of dead seedlings and the smallest mean $d$ and $h$ were noticed in 3/Pic. proportionally to $d$. In contrast, survival of container-grown $P$. palustris seedlings suddenly decreased when $d=10 \mathrm{~mm}$ and root-bound index (d/container cell diameter) was greater than $27 \%$ (South et al. 2005). In some studies, survival of seedlings has also been positively correlated with biomechanical traits such as stem tissue and leaf density and stem toughness, and it mirrors a trade-off between an investment of resources to growth, biomechanical traits and physiological mechanisms of defence against stressors (Alvarez-Clare and Kitajima 2007; Seiwa 2007).

In the present experiment, silver fir seedlings just began to acclimatize to the common growing environment although the differences among the seedling production technologies supported the hypothesis that the seedlings' growth was determined by pre-acclimatization to the nursery conditions where they were grown for three years. In earlier studies, in a two-year pot experiment, we found that in general, the amplitude of responses of silver fir to changing irradiance (phenotypic plasticity) was smaller than that recorded for broadleaved species. Under the canopies of different tree species, however, the artificial regeneration of fir showed 
significant growth and physiological plasticity (Robakowski et al. 2003, 2004). In our present study, all seedlings were grown in the open, thus these shade- and full-light acclimated, bareand ball root seedlings were exposed to the same stressors, such as high irradiance, high amplitudes of air temperature (especially late frosts) and water deficiency. Significant differences in survival and growth parameters in response to these stressors resulted from the interaction of the species-specific phenotypic plasticity of silver fir and initial acclimatization of seedlings to the nursery growth conditions.

In our experiment, the differences in LMA indicated that the needle structure acclimated to the light environments in the nurseries and it was unchanged during two seasons in plantation. The low LMA suggested that seedlings were acclimated to shade and might suffer from photoinhibition caused by high light when grown under full sun. On a global scale, plants with lower LMA are more efficient at light interception and net $\mathrm{CO}_{2}$ assimilation rates per unit leaf dry mass than those with the higher LMA (Wright et al. 2004). An increased LMA was observed in plants better-adapted to the high light environment (Ellsworth and Reich 1992; Le Roux et al. 1999; Evans and Poorter 2001). Our earlier results suggest that silver fir seedlings with higher LMA were better acclimated to the full light environment, and thus had an advantage over those with lower LMA growing before transplantation in a nursery under a canopy shade (Robakowski et al. 2003, 2004).

On the other hand, in the present study, 2/K seedlings with high survival and growth performance had also low LMA. This can be explained by the fact that roots of seedlings grown in Kosterkiewicz's ballots had better and more stable microclimatic, nutritional and mycorrhizal conditions for growth compared with bare-root seedlings grown one or three years in full light $(2 / \mathrm{g}, 3 / 0)$. A better developed and protected root system gave them an advantage over bare-root seedlings when grown in a full light environment and may compensate for the photoinhibitory stress in needles; however, the physiological mechanism of this compensation is unclear (Grossnickle 2005). It can be suggested that in our experiment ball root seedlings had a higher root growth potential compared with bare-root seedlings (Ritchie and Dunlap 1980).

\section{Quantum yield of PS II photochemistry}

In August, in the second growth season from planting, $\Phi_{\mathrm{PSII}}$ depended on the seedling production technology. Shade acclimated seedlings showed lower $\Phi_{\text {PSII }}$ than those grown at least one season in the open. The 3/Pic treatment showed the lowest $\Phi_{\mathrm{PSII}}$ compared with the 
other technologies. This may result from acclimation to shade and soil conditions of growth in the gaps of the Norway spruce stand. In a fifty-year experiment, Binkley and Valentine (1991) have shown that the Norway spruce soil is more acidic and contains less than half the quantity of exchangeable $\mathrm{Ca}^{2++}, \mathrm{Mg}^{2++}$ and $\mathrm{K}^{+}$in the 0-15-cm depth compared with the green ash soil. The decline in these cations under spruce crowns was accompanied by higher concentrations of exchangeable $\mathrm{Al}^{3+}$, which could be toxic for silver fir seedlings, as seen in the 3/Pic treatment (Boudot et al. 1993).

$\mathrm{F}_{\mathrm{v}} / \mathrm{F}_{\mathrm{m}}$ did not depend on the seedling production technology, except for April 2018 and May 2019, and seasonally varied concurrently with air temperature and light. A remarkable depression of $\mathrm{F}_{\mathrm{v}} / \mathrm{F}_{\mathrm{m}}$ was observed in all treatments during winter and in early spring, which was linked with the winter low temperatures and the late frosts and can be attributed to winter photoinhibition (Adams et al. 2004; Demmig-Adams and Adams III 2006). A decrease in $F_{v} / F_{m}$ was associated with increasing $F_{0}$, which can be interpreted as photoinhibitory damage due to the degradation of protein D1 in the reaction centres of PS II under low temperatures and high light. Decreasing $\mathrm{F}_{\mathrm{m}}$ values were related to enhanced nonphotochemical quenching via the xanthophyll cycle indicating photoprotection (Pospíšil et al. 1998; Yamazaki et al. 2007; Walter et al. 2011). In winter, lower $F_{m}$ values can be also due to a reduction of needle chlorophyll concentration, which protects the photosynthetic machinery against excessive energy (Robakowski 2005). The seasonal decrease of $F_{v} / F_{m}$ in silver fir seedlings found in our study can be regarded as transient photoinhibition which plays a photoprotective role at low temperatures and high light (Adams et al. 2004).

\section{Conclusions}

The seedling production technology affects survival, growth and to a lesser extent PS II photochemical efficiency of silver fir seedlings growing in plantation. The seedling production technologies tested in our study can be classified from the most suitable for planting of seedlings under the full light environment in the following order: $2 / \mathrm{K}>2 / \mathrm{g}>3 / 0$ $>$ 3/Pin > 3/Pic. Only bare-root seedlings acclimated to the Picea abies canopy shade had significantly lower survival and overall performance compared with those growing at least one season in the open or under the canopy of Pinus sylvestris. The $2 / \mathrm{K}$ seedling production technology was the most suitable for planting fir seedlings in the full light environment. Although some models predict that silver fir will find favourable conditions and will increase its natural occurrence range in the future climate regime, in local environmental conditions 
even within its natural range, the species may be threatened by stressors eliminating up to $50 \%$ of seedlings within two years depending on the seedling production technology.

Acknowledgements We would like to warmly thank Prof. W. Barzdajn for his help. We thank the State Forests Holding, Poland, for financial support. The publication is co-financed within the framework of Ministry of Science and Higher Education programme as "Regional Initiative Excellence” in years 2019-2022, project number 005/RID/2018/19.

\section{Literature}

Adams WW, III, Demming-Adams B (1994) Carotenoid composition and down regulation of photosystem II in three conifer species during the winter. Physiol Plantarum 92:451-498

Adams WW, III, Zarter CR, Ebbert V, Demmig-Adams B (2004) Photoprotective strategies of overwintering evergreens. BioScience 54:41-49

Alvarez-Clare S, Kitajima K (2007) Physical defence traits enhance seedling survival of neotropical tree species. Funct Ecol 21:1044-1054

Baker NR (2008) Chlorophyll fluorescence: a probe of photosynthesis in vivo. Annu Rev Plant Biol 59:89-113. doi: 10.1146/annurev.arplant.59.032607.092759

Barzdajn W (2000) Strategia restytucji jodły pospolitej (Abies alba Mill.) w Sudetach. [Strategy of silver fir (Abies alba Mill.) regeneration in Sudety Mts]. Sylwan 2:63-77 (in Polish)

Batavia Ch, Nelson MP (2016) Conceptual ambiguities and practical challenges of ecological forestry: a critical review. J For 114(5): 572-581. http://dx.doi.org/10.5849/jof.15-103

Binkley D, Valentine D (1991) Fifty-year biogeochemical effects of green ash, white pine, and Norway spruce in a replicated experiment. For Ecol Manage 40:13-25

Björkman O, Demmig B (1987) Photon yield of $\mathrm{O}_{2}$ evolution and chlorophyll fluorescence characteristics at $77 \mathrm{~K}$ among vascular plants of diverse origins. Planta 170:489-504

Bolibok L, Dobrowolska D (2016) Potencjalny zasięg klimatyczny jodły (Abies alba Mill.) w Polsce Potential climatic range for Abies alba Mill. in Poland. Sylwan 160:519-528

Boudot JP, Becquer T, Merlet D, Rouiller J (1993) Aluminium toxicity in declining forests: general overview with a seasonal assessment. Ann For Sci 51:27-51

Brang P, Spathelf P, Larsen JB et al (2014) Suitability of close-to-nature silviculture for adapting temperate European forests to climate change. Forestry 87(4):492-503. doi.org/10.1093/forestry/cpu018

Brzeziecki B, Kienast F (1994) Classifying the life history strategies of trees on the basis of the Grimian model. For Ecol Manage 69:167-187

Burdett AN (1990) Physiological processes in plantation establishment and the development 
of specifications for forest planting stock. Can J For Res 20:415-427. doi: 10.1139/x90059

Centre for Agriculture and Biosciences International (2005) Abies alba In: Forestry Compendium, Global Edition. Wallingford, UK: CAB International

Davis AS, Jacobs DF (2005) Quantifying root system quality of nursery seedlings and relationship to outplanting performance. New Forests 30:295-311. doi: 0.1007/s11056005-7480-y

Demmig-Adams B, Adams III W (2006) Photoprotection in an ecological context: the remarkable complexity of thermal energy dissipation. New Phytol 172:11-21. doi: 10.1111/j.1469-8137.2006.01835.x

Dobrowolska D, Bolibok L (2019) Is climate the key factor limiting the natural regeneration of silver fir beyond the northeastern border of its distribution range ? For Ecol Manage 439:105-121. doi: 10.1016/j.foreco.2019.02.040

Dobrowolska D, Bončina A, Klumpp R (2017) Ecology and silviculture of silver fir (Abies alba Mill.): A review. J For Res 22:326-335. doi: 10.1080/13416979.2017.1386021

Dumroese RK, Landis TD, Pinto JR, Haase DL, Wilkinson KW, Davis AS (2016) Meeting forest restoration challenges: Using the target plant concept. Reforesta 1:37-52. doi: http://dx.doi.org/10.21750/REFOR.1.03.3

Dyderski MK, Paź S, Frelich LE, Jagodziński AM (2018) How much does climate change threaten European forest tree species distributions? Global Change Biol 24(3):11501163

Elling W, Dittmar C, Pfaffelmoser K, Rötzer T (2009) Dendroecological assessment of the complex causes of decline and recovery of the growth of silver fir (Abies alba Mill.) in Southern Germany. For Ecol Manage 257:1175-1187

Ellsworth DS, Reich PB (1992) Leaf mass per area, nitrogen content and photosynthetic carbon gain in Acer saccharum seedlings in contrasting forest light environments. Funct Ecol 6:423-435

Evans JR, Poorter H (2001) Photosynthetic acclimation of plants to growth irradiance: the relative importance of specific leaf area and nitrogen partitioning in maximizing carbon gain. Plant, Cell Environ 24:755-767

Genty B, Briantais J-M., Baker NR (1989) The relationship between the quantum yield of photosynthetic electron transport and quenching of chlorophyll fluorescence. Biochim et Biophys Acta 990:87-92

Gostyńska-Jakuszewska M (1972) Jodła pospolita (Abies alba Mill.), w: Atlas rozmieszczenia drzew i krzewów w Polsce. [Silver fir (Abies alba Mill.), in: Atlas of distribution of trees and shrubs in Poland] K. Browicz (ed.). PWN, Warszawa- Poznań, Vol. 12:5-10.

Grossnickle SC (1988) Planting stress in newly planted jack pine and white spruce. 2 Changes in tissue water potential components. Tree Physiol 4:85-97.

Grossnickle SC (2005) Importance of root growth in overcoming planting stress. New Forests 30:273-294. doi: 10.1007/s11056-004-8303-2 
575 Grossnickle SC (2012) Why seedlings survive: influence of plant attributes. New Forests 576 43:711-738. doi: 10.1007/s11056-012-9336-6

577 Grossnickle SC, El-Kassaby YA (2015) Bareroot versus container stocktypes: a performance

Häsler H, Senn J, Edwards J (2008) Light-dependent growth responses of young Abies alba to simulated ungulate browsing. Funct Ecol 22(1):48-57. doi: 10.1111/j.1365-2435.2007.0

Hobbie SE, Ogdahl M, Chorover J et al. (2007) Tree species effects on soil organic matter dynamics: the role of soil cation composition. Ecosystems 10:999-1018. doi: $10.1007 / \mathrm{s} 10021-007-9073-4$

Kalaji HM, Jajoo A, Oukarroum A (2016) Chlorophyll a fluorescence as a tool to monitor physiological status of plants under abiotic stress conditions. Acta Physiol Plant 38:102. doi 10.1007/s11738-016-2113-y

Kazda M, Salzer J, Schmid I, von Wrangell Ph (2004) Importance of mineral nutrition for photosynthesis and growth of Quercus petraea, Fagus sylvatica and Acer pseudoplatanus planted under Norway spruce canopy. Plant Soil 264:25-34. doi.org/10.1023/B:PLSO.0000047715.95176.63

Kozlowski TT and SG Pallardy (2002) Acclimation and adaptive responses of woody plants to environmental stresses. Bot Rev 68:270. doi.org/10.1663/00068101(2002)068[0270:AAAROW]2.0.CO;2

Krause GH, Winter K, Matsubara S (2012) Photosynthesis, photoprotection, and growth of shade-tolerant tropical tree seedlings under full sunlight. Photosynth Res. doi: $10.1007 / \mathrm{s} 11120-012-9731-\mathrm{z}$

Kromdijk J, Głowacka K, Leonelli L et al. (2016) Improving photosynthesis and crop productivity by accelerating recovery from photoprotection. Science 354(6314):857-860

Lauriano JA, Ramalho JC, Lidon FC, Céumatos M (2006) Mechanisms of energy dissipation in peanut under water stress. Photosynthetica 44(3):404-410

Le Roux X, Sinoquet H, Vandame M (1999) Spatial distribution of leaf weight per area and leaf nitrogen content in relation to local radiation regime within an isolated tree crown. Tree Physiol 19:181-188.

Lüttge U, Berg A, Fetene M, Nauke P, Dirk P, Beck E (2003) Comparative characterization of photosynthetic performance and water relations of native trees and exotic plantation trees in Ethiopian forest. Trees, 17(1):40-50

Margolis MA, Brand DG (1990) An ecophysiological basis for understanding plantation establishment. Can J For Res 20:375-390

Maxwell K, Johnson NG (2000) Chlorophyll fluorescence - A practical guide. J Exp Bot 51:659-668.

Mohammed G, Parker W (1999) Photosynthetic acclimation in eastern hemlock [Tsuga canadensis (L.) Carr.] seedlings following transfer of shade-grown seedlings to high light. Trees 13, 117-124. doi.org/10.1007/PL00009743 
Mueller KE, Hobbie SE, Chorover J et al. (2015) Effects of litter traits, soil biota, and soil chemistry on soil carbon stocks at a common garden with 14 tree species. Biogeochemistry 123(3):313-327. Doi: 10.1007/s10533-015-0083-6

Naramoto M, Katahata S, Mukai Y, Kakubari Y (2006) Photosynthetic acclimation and photoinhibition on exposure to high light in shade-developed leaves of Fagus crenata seedlings. Flora 201(2):120-126. doi.org/10.1016/j.flora.2005.04.008

Oliet JA, Jacobs DF (2012) Restoring forests: Advances in techniques and theory. New Forests 43:535-541. doi: 10.1007/s11056-012-9354-4

Pospíšil P, Skotnica J, Nauš J (1998) Low and high temperature dependence of minimum F0 and maximum $\mathrm{F}(\mathrm{M})$ chlorophyll fluorescence in vivo. Biochim Biophys Acta - Bioenerg 1363:95-99. doi: 10.1016/S0005-2728(97)00095-9

Puértolas J, Benito LF, Peñuelas JL (2009) Effects of nursery shading on seedling quality and post-planting performance in two Mediterranean species with contrasting shade tolerance. New For 38:295-308. doi: 10.1007/s11056-009-9148-5

Rietveld WJ (1989) Transplanting stress in bareroot conifer seedlings: Its development and progression to establishment. Northern Journal of Applied Forestry 6(3):99-107. doi.org/10.1093/njaf/6.3.99

Ritchie GA, Dunlap JR (1980) Root potential, its development and expression in forest tree seedlings. NZJ For Sci, 10 10:218-248

Robakowski P, Monpied P, Dreyer E (2003) Plasticity of morphological and physiological traits in response to different levels of irradiance in seedlings of silver fir (Abies alba Mill). Trees 17:431-441

Robakowski P, Wyka T (2003) Acclimation of silver fir (Abies alba Mill.) seedlings to irradiance conditions under canopies of different tree species in Sudety Mts. Polish Journal of Ecology 51(3):323-337

Robakowski P, Wyka T, Samardakiewicz S, Kierzkowski D (2004) Growth, photosynthesis, and needle structure of silver fir (Abies alba Mill.) seedlings under different canopies. For Ecol Manage 201:211-227.

Robakowski P (2005) Susceptibility to low-temperature photoinhibition in three conifers differing in successional status. Tree Physiol 25:1151-1160.

Ruban A V (2015) Evolution under the sun: optimizing light harvesting in photosynthesis. J Exp Bot 66:7-23. doi: 10.1093/jxb/eru400

Ruotsalainen S (2014) Increased forest production through forest tree breeding. Scand J For Res 29:333-344. doi: 10.1080/02827581.2014.926100

Seiwa K (2007) Trade-offs between seedling growth and survival in deciduous broadleaved trees in a temperate forest. Ann Bot 99(3):537-544.

South DB, Harris SW, Barnett JP, Hainds MJ, Gjerstada DH (2005) Effect of container type and seedling size on survival and early height growth of Pinus palustris seedlings in Alabama, U.S.A. For Ecol Manage 204(2-3):385-398.

South DB and JG Mexal (1984) Growing "the best” seedling for reforestation success. 
Alabama Agricultural Experimental Station, Auburn Univesrity, Forestry Departmental Series 12:1-11

Vitasse Y, Bottero A, Rebetez M, et al (2019) What is the potential of silver fir to thrive under warmer and drier climate ? Eur J For Res. doi: 10.1007/s10342-019-01192-4

Walter J, Nagy L, Hein R, Rascher U, Beierkuhnlein C, Willner E, Jentsch A (2011) Do plants remember drought? Hints towards a drought-memory in grasses. Environ Exp Bot 71:34-40.

Wright IJ, Reich PB, Westoby M, Ackerly DD, Baruch Z, Bongers F, Cavender-Bares J, Chapin T, Cornelissen JHC, Diemer M, et al. (2004) The worldwide leaf economics spectrum. Nature 428:821-827.

Yamazaki J-Y, Tsuchiya S, Nagano S, Maruta E (2007) Photoprotective mechanisms against winter stresses in the needles of Abies mariesii grown at the tree line on Mt. Norikura in Central Japan. Photosynthetica 45:547-554. doi: 10.1007/s11099-007-0094-1

Ye Z-P, Robakowski P, Suggett DJ (2012) A mechanistic model for the light response of photosynthetic electron transport rate based on light harvesting properties of photosynthetic pigment molecules. Planta. doi: 10.1007/s00425-012-1790-z

Zawada J (2001) Przyrostowe objawy rewitalizacji jodły w lasach Karpat i Sudetów oraz wynikające z nich konsekwencje hodowlane. [Growth symptoms of fir revitalization in the Carpathian and Sudety forests and its silvicultural consequences] Forest Research Papers A, 922:79-101.

\section{Captions of tables}

Table 1. The localization and conditions of Abies alba seedling production using five stock types (seedling production technologies) in Forest Division "Miedzylesie". 3/Pic - bare-root seedling, three years in an opening in a Picea abies stand (65\% of full light); 3/Pin - bare-root seedling, three years under a Pinus sylvestris canopy (35 - $40 \%$ of full light); 2/K - ball seedling, two years under a shading net (40\% of full light), one year in Kosterkiewicz' ballot in the open; $2 / \mathrm{g}$ - bare-root seedling, two years under a shading net (40\% of full light), a year in the open; 3/0 - bare-root seedling, three years in an open nursery

Table 2. Monthly sums of photosynthetic photon flux density (PPFD), air temperature, air humidity and volumetric soil water content when measurements of chlorophyll $a$ fluorescence were conducted. $T_{\text {mean }}$ - mean monthly temperature, $T_{\min }$ - minimum monthly temperature, $T_{\max }$ - maximum monthly temperature, $R H_{\text {mean }}$ - mean monthly relative humidity, $R H_{\min }-$ minimum monthly relative humidity, $V W C$ - volumetric soil water content at $15 \mathrm{~cm}, \mathrm{SE}-$ standard error. Maximum monthly relative humidity $\left(R H_{\max }\right)$ was $100 \%$ each month 
695 Table 3. Percentage survival (mean \pm SD) of Abies alba seedlings grown in forest nurseries

696 using one of five methods. Survival was assessed in September 2018. 3/Pic - bare-root seedling, three years in an opening in a Picea abies stand (65\% of full light); 3/Pin - bare-root seedling, three years under a Pinus sylvestris canopy ( $35-40 \%$ of full light); $2 / \mathrm{K}$ - ball seedling, two years under a shading net (40\% of full light), one year in Kosterkiewicz' ballot in the open; $2 / \mathrm{g}$ - bare-root seedling, two years under a shading net (40\% of full light), a year in the open; 3/0 - bare-root seedling, three years in an open nursery. Percentage values were transformed with the Bliss function prior to one-way ANOVA. $D f$-degrees of freedom; $F-$ value of Snedecor's function; $P$ - probability. The same letters indicate that the mean values are not different in Duncan's a posteriori test at $\alpha=0.05$

Table 4. Results of the one-way analysis of variance (ANOVA) for diameter at root collar (d), height (h) and degree of slenderness (h/d) of Abies alba seedlings prepared with one of five technologies: 3/Pic - bare-root seedling, three years in an opening in a Picea abies stand; 3/Pin - bare-root seedling, three years under a Pinus sylvestris canopy (3/Pin); 2/K - ball seedling, two years under a shading net, one year in Kosterkiewicz' ballot in the open; $2 / \mathrm{g}-$ bare-root seedling, two years under a shading net, a year in the open; 3/0 - bare-root seedling, three years in an open nursery. SPT - seedling production technology; $D f$-degrees of freedom; SS - sum of squares; MS - mean sum of squares; $F$ - value of Snedecor's function;

Table 5. The values of Pearson's coefficients of correlation between climatic parameters, soil volumetric water content and fluorescence parameters. Chlorophyll $a$ fluorescence was measured each month from 20 May 2018 to 20 May 2019 ( $n=50, n=$ number of seedlings used for measurements each month). All climatic parameters were calculated as the mean or sum values from 10 days before the date of chlorophyll $a$ fluorescence measurements. $\Sigma$ PPFD - sum of the values of photosynthetic photon flux density $\left(\mathrm{mmol} \mathrm{m}^{-2}\right.$ day $\left.^{-1}\right) ; T_{\text {mean }}$ - mean air temperature $\left({ }^{\circ} \mathrm{C}\right) ; T_{\min }$ - minimum air temperature in 10 days before the date of fluorescence measurements $\left({ }^{\circ} \mathrm{C}\right) ; T_{\max }$ - maximum air temperature in 10 days before the date of fluorescence measurements $\left({ }^{\circ} \mathrm{C}\right)$; $\Sigma$ Precip - sum of precipitation $(\mathrm{mm}) ; R H_{\text {mean }}$ - mean relative humidity (\%); $R H_{\min }$ - minimum relative humidity $(\%)$; VWC - mean volumetric soil water content at $15 \mathrm{~cm}(\%) ; \mathrm{F}_{\mathrm{v}} / \mathrm{F}_{\mathrm{m}}$ - maximum quantum yield of PSII photochemistry; $\mathrm{F}_{0}$ - basic 
727 fluorescence yield; $\mathrm{F}_{\mathrm{m}}$ - maximum fluorescence yield. ( $* * * P<0.001 ; n=12, n-$ number of

728 pairs of values)

729

730

731

732

Captions of figures

733

734

Fig 1 The layout of the experiment

735

736

Fig 2 The logistic regressions: probability of survival vs. stem diameter at root collar (a), probability of survival $v s$. height (b). Silver fir seedlings were prepared with one of five technologies in forest nurseries. Each point represents the value of survival probability per seedling production technology per block. Equations of logistic regression, coefficients of determination $\left(R^{2}\right)$ with probability $(* * * P<0.001)$ are shown. $d$-diameter at root collar; $h-$ height

Fig 3 (a) Stem diameter at root collar $(d)$, (b) height $(h)$ and (c) degree of slenderness $(h / d)$ (means $\pm \mathrm{SD}$ ) of silver fir seedlings grown in forest nurseries using one of five technologies. The same letters (2017 - small letters, 2018 - capital letters) above columns indicate that the mean values do not differ among the seedling production technologies in Duncan's post-hoc test at $\alpha=0.05$ (in $2017 n=2397$, in $2018 n=2050$ ). 3/Pic - bare-root seedling, three years in an opening in a Picea abies stand; 3/Pin - bare-root seedling, three years under a Pinus sylvestris canopy; $2 / \mathrm{K}$ - ball seedling, two years under a shading net, one year in Kosterkiewicz' ballot in the open; 2/g - bare-root seedling, two years under a shading net, a year in the open; 3/0 - bare-root seedling, three years in an open nursery. For ANOVA results see Table 3

Fig 4 The leaf mass-to-area ratio (LMA, means \pm SE) of Abies alba seedlings prepared with one of five seedling production technologies in forest nurseries prior to planting. Needle samples were collected from seedlings in the second growing season, in August 2018. The same letters above columns indicate that the mean values do not differ among the methods of seedling production in Duncan's post-hoc test at $\alpha=0.05(n=25, n-$ number of replicates per treatment). For abbreviations, see the caption of Fig 1. 
761 Fig 5 Quantum yield of PS II efficiency ( $\Phi_{\mathrm{PSII}}$, means \pm SE) measured in Abies alba needles

762 illuminated a priori with actinic light $\left(\mathrm{PPF}=350 \mu \mathrm{mol} \mathrm{m}^{-2} \mathrm{~s}^{-1}\right)$ after stabilization of steady

763 state fluorescence $\left(F_{s}\right)$. The same letters above columns indicate that the mean values do not

764 differ among the seedling production technologies in Duncan's post-hoc test at $\alpha=0.05$ ( $n=$

765 25). For abbreviations, see the caption of Fig 1

766

767 Fig 6 Time-course of maximum quantum yield of PSII photochemistry $\left(F_{v} / F_{m}\right)$, basic

768 fluorescence yield $\left(\mathrm{F}_{0}\right)$ and maximum fluorescence yield $\left(\mathrm{F}_{\mathrm{m}}\right)$ monitored in needles of Abies

769 alba seedlings grown in forest nurseries using one of five technologies during 3 years and

770 planted in the open (means, $n=10$ ). Results of one-way ANOVA at $p \leq 0.05$ are shown. The

771 significant differences among mean values in Duncan's test within the date of fluorescence

772 measurements are marked with asterisks $(* * * P<0.001)$

773

774 Tables and figures

775

776

Table 1.

\begin{tabular}{|c|c|c|c|}
\hline Stock type & Relief / localization & Type of soil / substrate & Light conditions \\
\hline 3/Pic & $\begin{array}{l}\text { Mid slope, NW } \\
\text { exposure / Mountainous } \\
\text { Fresh Forest, nursery in } \\
\text { a gap of Picea abies } \\
\text { stand }\end{array}$ & Brown soil & $\begin{array}{l}65 \% \text { of full sun light, } \\
\text { side shade of Picea } \\
\text { abies stand }\end{array}$ \\
\hline 3/Pin & $\begin{array}{l}\text { Flat / undercanopy } \\
\text { Pinus sylvestris } \\
\text { nursery, Mixed } \\
\text { Mountainous Fresh } \\
\text { Forest }\end{array}$ & Brown soil & $\begin{array}{l}35-40 \% \text { of full sun } \\
\text { light, under the Pinus } \\
\text { sylvestris canopy }\end{array}$ \\
\hline $2 / \mathrm{K}$ & $\begin{array}{l}\text { Flat / shading net, open } \\
\text { nursery }\end{array}$ & $\begin{array}{l}\text { Brown soil, peat and } \\
\text { perlite }(50 \%) \text { / forest soil } \\
\text { and sawdusts }(50 \%)\end{array}$ & $\begin{array}{l}2 \text { years under a } \\
\text { shading net ( } 40 \% \text { of } \\
\text { full light), a year in } \\
\text { full sun light }\end{array}$ \\
\hline $2 / g$ & $\begin{array}{l}\text { Flat / shading net, open } \\
\text { nursery }\end{array}$ & Brown soil & $\begin{array}{l}2 \text { years under a } \\
\text { shading net ( } 40 \% \text { of } \\
\text { full light), a year in } \\
\text { full sun light }\end{array}$ \\
\hline $3 / 0$ & Flat / open nursery & Brown soil & Full sun light \\
\hline
\end{tabular}

777 
Table 2

\begin{tabular}{llllllll}
\hline Date & $\begin{array}{l}P P F D_{\text {sum }} \\
\left(\mathrm{mmol} \mathrm{m}^{-2}\right. \\
\left.\text { month }^{-1}\right)\end{array}$ & $\begin{array}{l}T_{\text {man }} \\
\left( \pm \mathrm{SE},{ }^{\circ} \mathrm{C}\right)\end{array}$ & $\begin{array}{l}T_{\min }-T_{\max } \\
\left({ }^{\circ} \mathrm{C}\right)\end{array}$ & $\begin{array}{l}R H_{\text {mean }} \\
( \pm \mathrm{SE}, \\
\%)\end{array}$ & $\begin{array}{l}R H_{\min } \\
(\%)\end{array}$ & $\begin{array}{l}\text { Monthly } \\
\text { sums of } \\
\text { precip. } \\
(\mathrm{mm})\end{array}$ & $\begin{array}{l}\mathrm{VWC} \\
(\%)\end{array}$ \\
\hline April 2018 & - & $12.2 \pm 0.3$ & $-6.5-32.5$ & $75 \pm 0.9$ & 26 & - & $26.3 \pm 0.5$ \\
May 2018 & 1204 & $14.9 \pm 0.3$ & $-2.3-33.2$ & $77 \pm 0.8$ & 29 & 51 & $26.0 \pm 0.7$ \\
Jun 2018 & 1032 & $17.2 \pm 0.3$ & $1.0-36.9$ & $78 \pm 0.8$ & 29 & 71 & $24.7 \pm 0.6$ \\
July 2018 & 1195 & $18.1 \pm 0.3$ & $-0.6-38.8$ & $77 \pm 0.9$ & 20 & 91 & $26.0 \pm 1.6$ \\
August 2018 & 892 & $19.4 \pm 0.3$ & $-1.3-41.0$ & $73 \pm 0.9$ & 19 & 25 & $21.4 \pm 1.3$ \\
September 2018 & 624 & $13.4 \pm 0.3$ & $-5.6-36.1$ & $81 \pm 0.8$ & 19 & 61 & $24.8 \pm 1.5$ \\
October 2018 & 424 & $9.5 \pm 0.3$ & $-6.9-27.4$ & $82 \pm 0.7$ & 32 & 76 & $26.1 \pm 1.8$ \\
November 2018 & 191 & $3.2 \pm 0.2$ & $-11.4-20.2$ & $91 \pm 0.5$ & 33 & 25 & $28.9 \pm 0.3$ \\
December 2018 & 62 & $0.9 \pm 0.1$ & $-10.0-10.2$ & $96 \pm 0.2$ & 54 & 100 & $30.1 \pm 1.0$ \\
January 2019 & 106 & $-2.9 \pm 0.2$ & $-17.3-5.8$ & $95 \pm 0.2$ & 62 & 81 & $30.1 \pm 2.1$ \\
February 2019 & 308 & $0.5 \pm 0.2$ & $-15.4-19.5$ & $89 \pm 0.6$ & 27 & 38 & $30.1 \pm 1.5$ \\
March 2019 & 475 & $5.2 \pm 0.2$ & $-6.8-26.9$ & $82 \pm 0.6$ & 28 & 46 & $30.8 \pm 0.5$ \\
April 2019 & 886 & $8.4 \pm 0.3$ & $-8.3-31.6$ & $73 \pm 0.8$ & 22 & 43 & $29.1 \pm 0.7$ \\
May 2019 & 851 & $9.9 \pm 0.3$ & $-6.3-29.9$ & $84 \pm 0.7$ & 33 & 152 & $30.6 \pm 0.9$ \\
\hline
\end{tabular}


803

$804 \quad$ Table 3

\begin{tabular}{ll}
\hline $\begin{array}{l}\text { Technology of } \\
\text { seedlings production }\end{array}$ & $\begin{array}{l}\text { Mean Percent } \\
\text { Survival }( \pm \mathrm{SD})\end{array}$ \\
\hline 3/Pic & $67 \pm 10 \mathrm{a}$ \\
3/Pin & $84 \pm 6 \mathrm{~b}$ \\
2/K & $92 \pm 4 \mathrm{~b}$ \\
$2 / \mathrm{g}$ & $90 \pm 6 \mathrm{~b}$ \\
$3 / 0$ & $81 \pm 13 \mathrm{~b}$ \\
\hline$F_{4,16}=6.3$ & $P=0.003$ \\
\hline
\end{tabular}

805

806

807

808

809

810

811

812

813

814

815

816

817

818

819

820 
Table 4

\begin{tabular}{|c|c|c|c|c|c|c|c|}
\hline Year & Parameter & Effect & $\overline{D f}$ & $S S$ & $M S$ & $F$ & $P$ \\
\hline \multirow{12}{*}{2017} & \multirow{4}{*}{ d } & SPT & 4 & 8.453 & 2.113 & 5.318 & 0.006 \\
\hline & & Block & 4 & 3.179 & 0.795 & 1.999 & 0.143 \\
\hline & & Error & 16 & 6.359 & 0.397 & & \\
\hline & & Total & 24 & 17.99 & & & \\
\hline & \multirow{4}{*}{ h } & SPT & 4 & 2419.099 & 604.775 & 2.404 & 0.093 \\
\hline & & Block & 4 & 2585.805 & 646.451 & 2.570 & 0.078 \\
\hline & & Error & 16 & 4024.581 & 251.536 & & \\
\hline & & Total & 24 & 9029.484 & & & \\
\hline & \multirow{4}{*}{$\mathrm{h} / \mathrm{d}$} & SPT & 4 & 26.828 & 6.707 & 2.953 & 0.053 \\
\hline & & Block & 4 & 156.566 & 39.142 & 17.233 & $<0.001$ \\
\hline & & Error & 16 & 36.341 & 2.271 & & \\
\hline & & Total & 24 & 219.735 & & & \\
\hline \multirow{12}{*}{2018} & \multirow{4}{*}{ d } & SPT & 4 & 7.949 & 1.987 & 6.644 & 0.002 \\
\hline & & Block & 4 & 10.114 & 2.528 & 8.453 & 0.001 \\
\hline & & Error & 16 & 4.786 & 0.299 & & \\
\hline & & Total & 24 & 22.849 & & & \\
\hline & \multirow{4}{*}{$\mathrm{h}$} & SPT & 4 & 8337.342 & 2084.336 & 4.323 & 0.015 \\
\hline & & Block & 4 & 6338.626 & 1584.656 & 3.287 & 0.038 \\
\hline & & Error & 16 & 7713.813 & 482.113 & & \\
\hline & & Total & 24 & 22389.78 & & & \\
\hline & \multirow{4}{*}{$\mathrm{h} / \mathrm{d}$} & SPT & 4 & 53.184 & 13.296 & 1.830 & 0.172 \\
\hline & & Block & 4 & 62.061 & 15.515 & 2.135 & 0.124 \\
\hline & & Error & 16 & 116.258 & 7.266 & & \\
\hline & & Total & 24 & 231.504 & & & \\
\hline
\end{tabular}

828

829

830

831

832

833

834 
Table 5

\begin{tabular}{|c|c|c|c|c|c|c|c|c|c|c|c|}
\hline & $\Sigma$ PPFD & $T_{\text {mean }}$ & $T_{\min }$ & $T_{\max }$ & $\Sigma$ Precip & $R H_{\text {mean }}$ & $R H_{\min }$ & VWC & $\mathrm{F}_{\mathrm{v}} / \mathrm{F}_{\mathrm{m}}$ & $\mathrm{F}_{0}$ & $\mathrm{~F}_{\mathrm{m}}$ \\
\hline $\mathrm{F}_{\mathrm{v}} / \mathrm{F}_{\mathrm{m}}$ & $\begin{array}{l}0.65 \\
*\end{array}$ & $\begin{array}{l}0.78 \\
* *\end{array}$ & $\begin{array}{l}0.75 \\
* *\end{array}$ & $\begin{array}{l}0.71 \\
* *\end{array}$ & $\begin{array}{l}0.59 \\
*\end{array}$ & n.s. & $\begin{array}{l}-0.72 \\
* *\end{array}$ & n.s. & - & $\begin{array}{l}-0.86 \\
* * *\end{array}$ & n.s. \\
\hline $\mathrm{F}_{0}$ & $\begin{array}{l}-0.55 \\
*\end{array}$ & $\begin{array}{l}-0.61 \\
*\end{array}$ & $\begin{array}{l}-0.61 \\
*\end{array}$ & n.s. & n.s. & n.s. & n.s. & n.s. & $\begin{array}{l}-0.86 \\
* * *\end{array}$ & - & n.s. \\
\hline $\mathrm{F}_{\mathrm{m}}$ & n.s. & n.s. & n.s. & n.s. & n.s. & n.s. & n.s. & $\begin{array}{l}-0.57 \\
*\end{array}$ & n.s. & n.s. & - \\
\hline
\end{tabular}




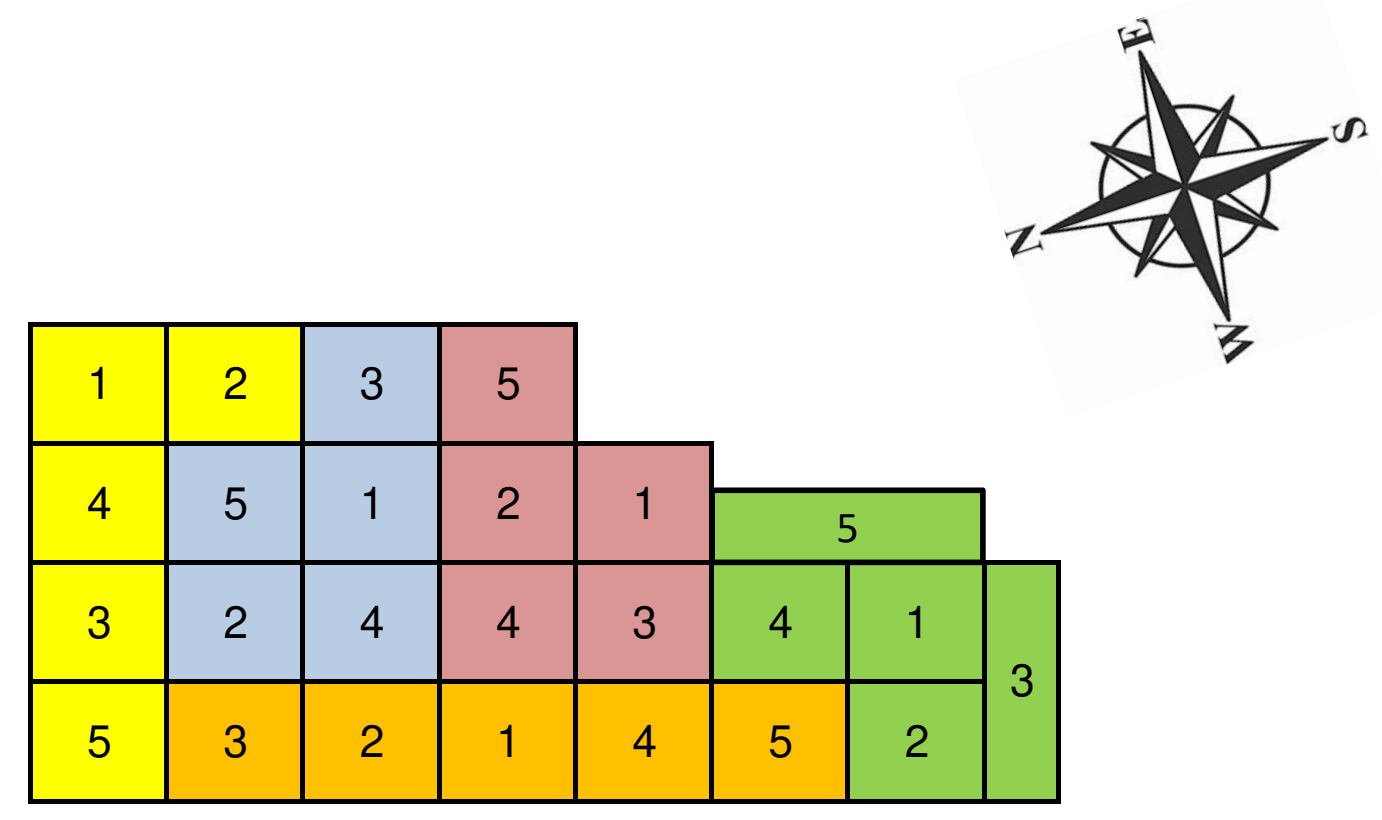

Blocks:

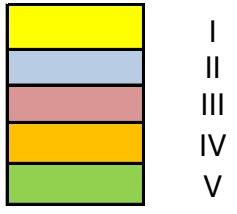

Seedling production technology:

$13 / 0$ bare-root seedling, three years in the open nursery

$23 /$ Pin bare-root seedling, three years under the Pinus sylvestris (L.) canopy

3 3/Pic bare-root seedling, three years in opening in a Norway spruce (Picea abies Karst.) stand

$4 \quad 2 / g$ bare-root seedling, two years under a shading net, a year in the open

$859 \quad$ Fig. 1 


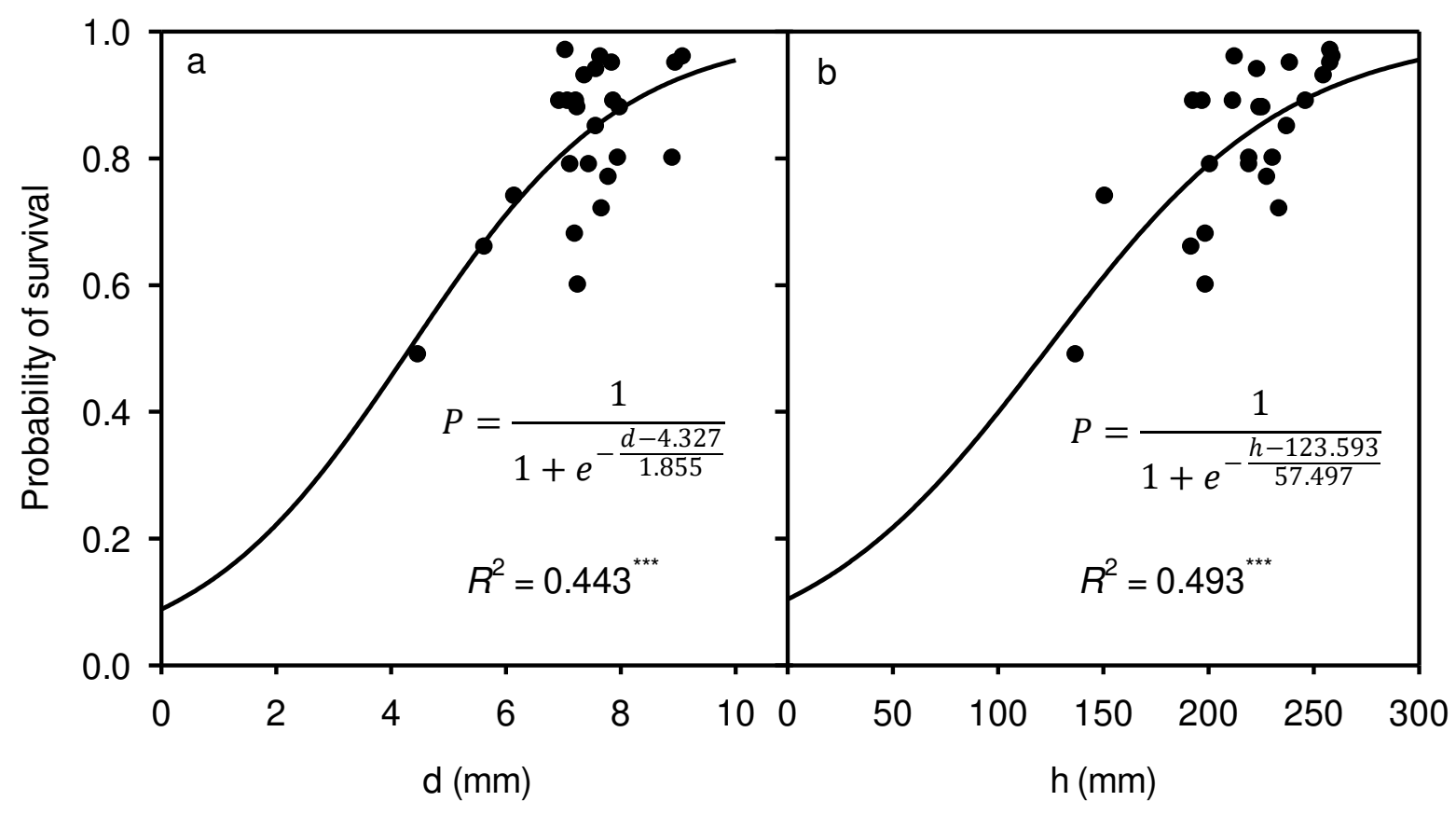

860

Fig. 2 


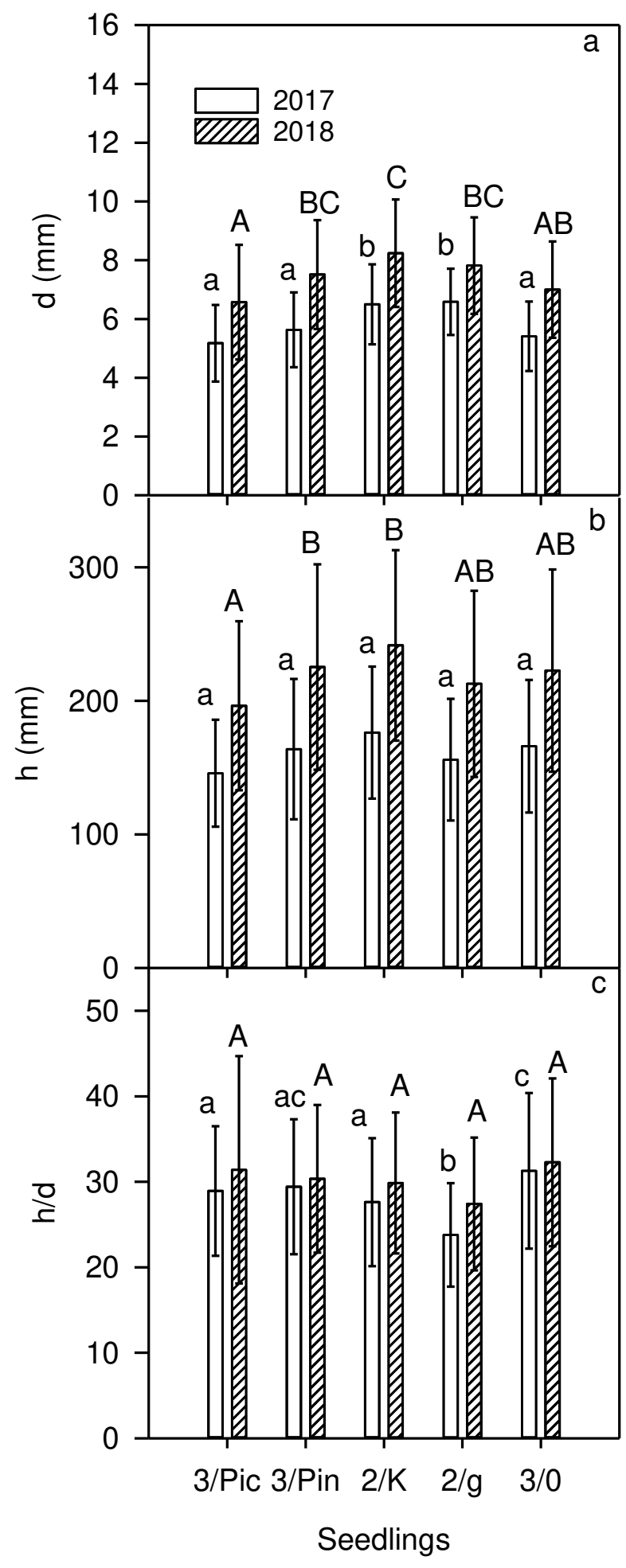

870

871

$872 \quad$ Fig. 3

873

874

875 


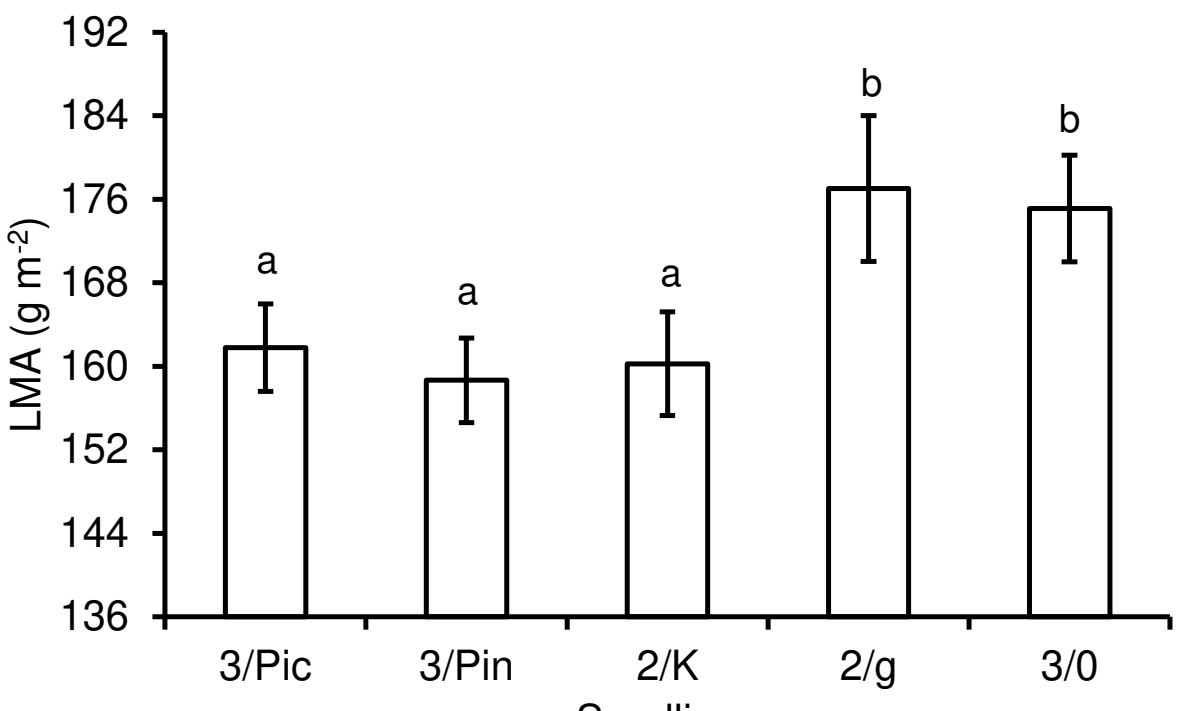

877

Seedlings

$878 \quad$ Fig 4

879

880

881

882

883

884

885

886

887

888

889

890

891

892

893

894 


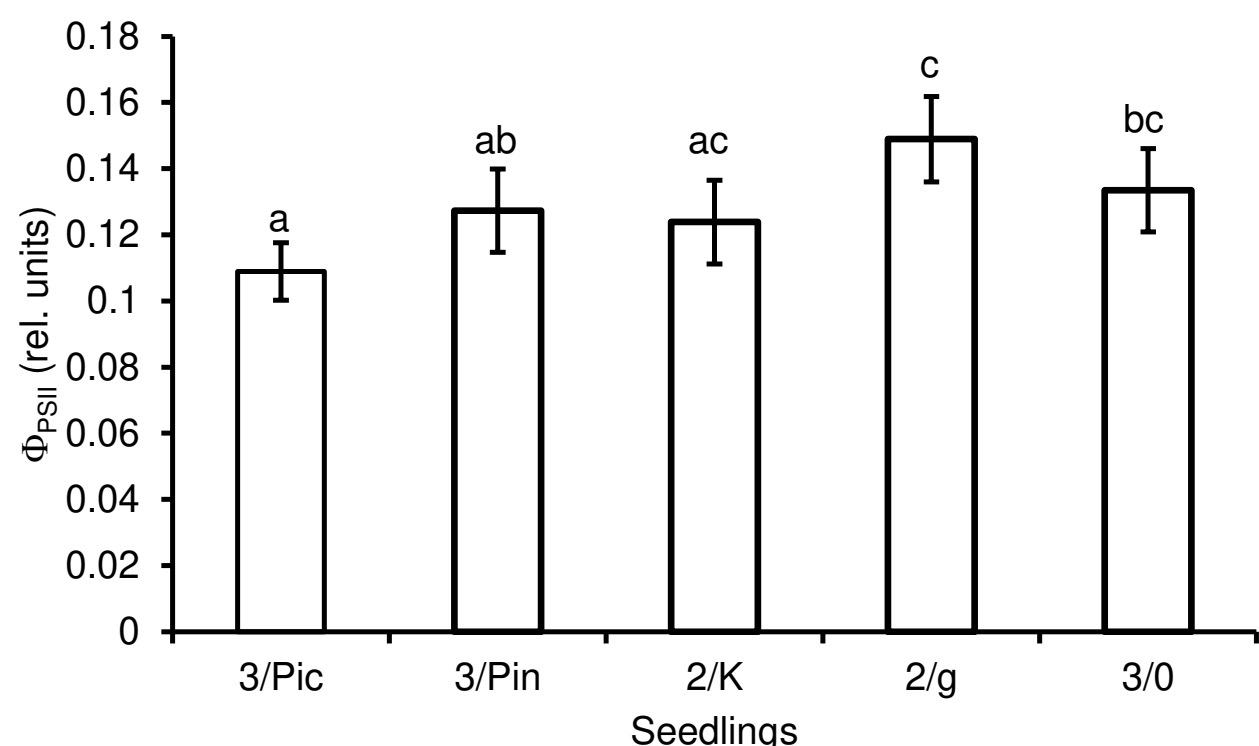

896

$897 \quad$ Fig 5

898

899

900

901

902

903

904

905

906

907

908

909

910

911 


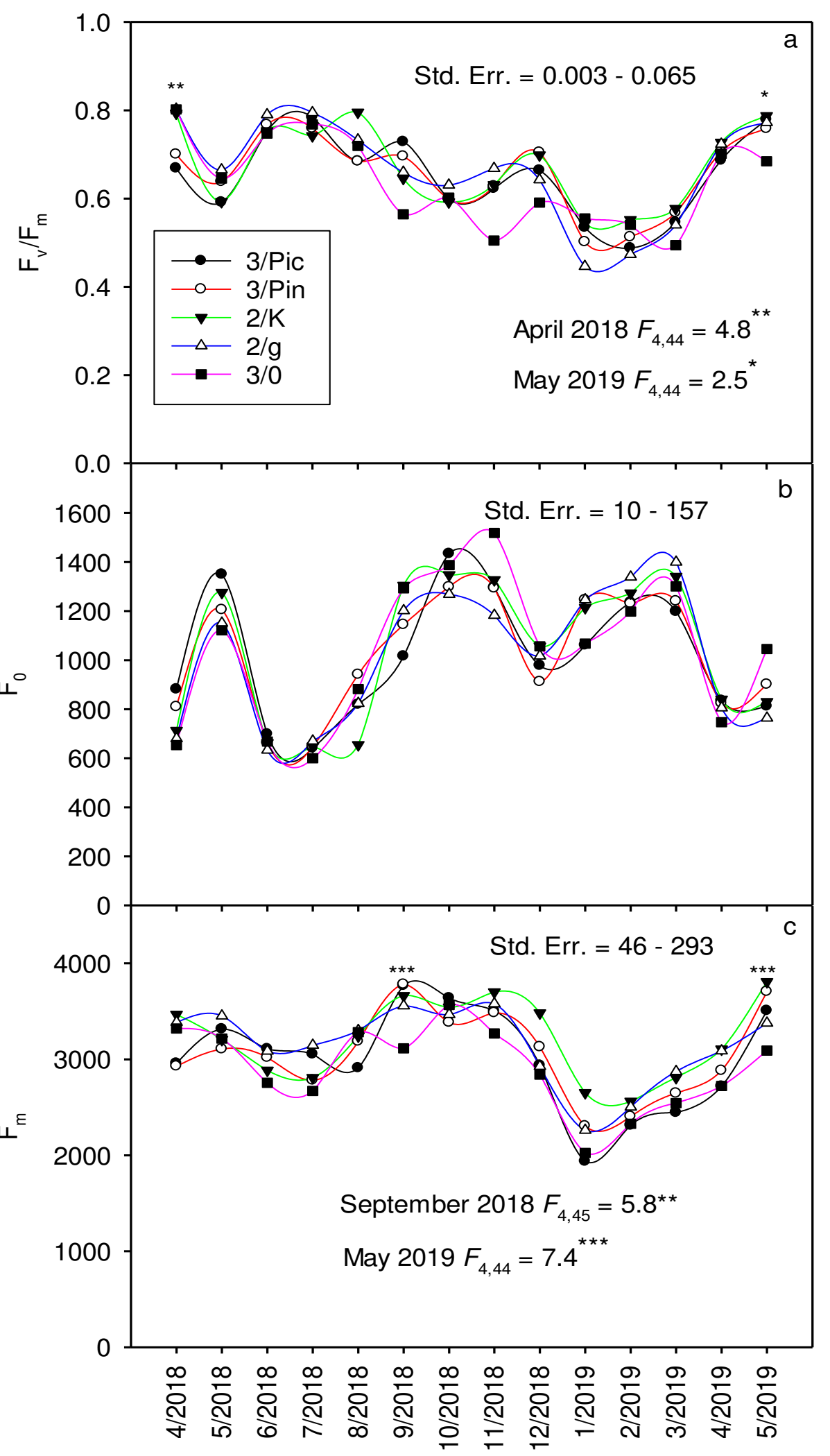


Figures

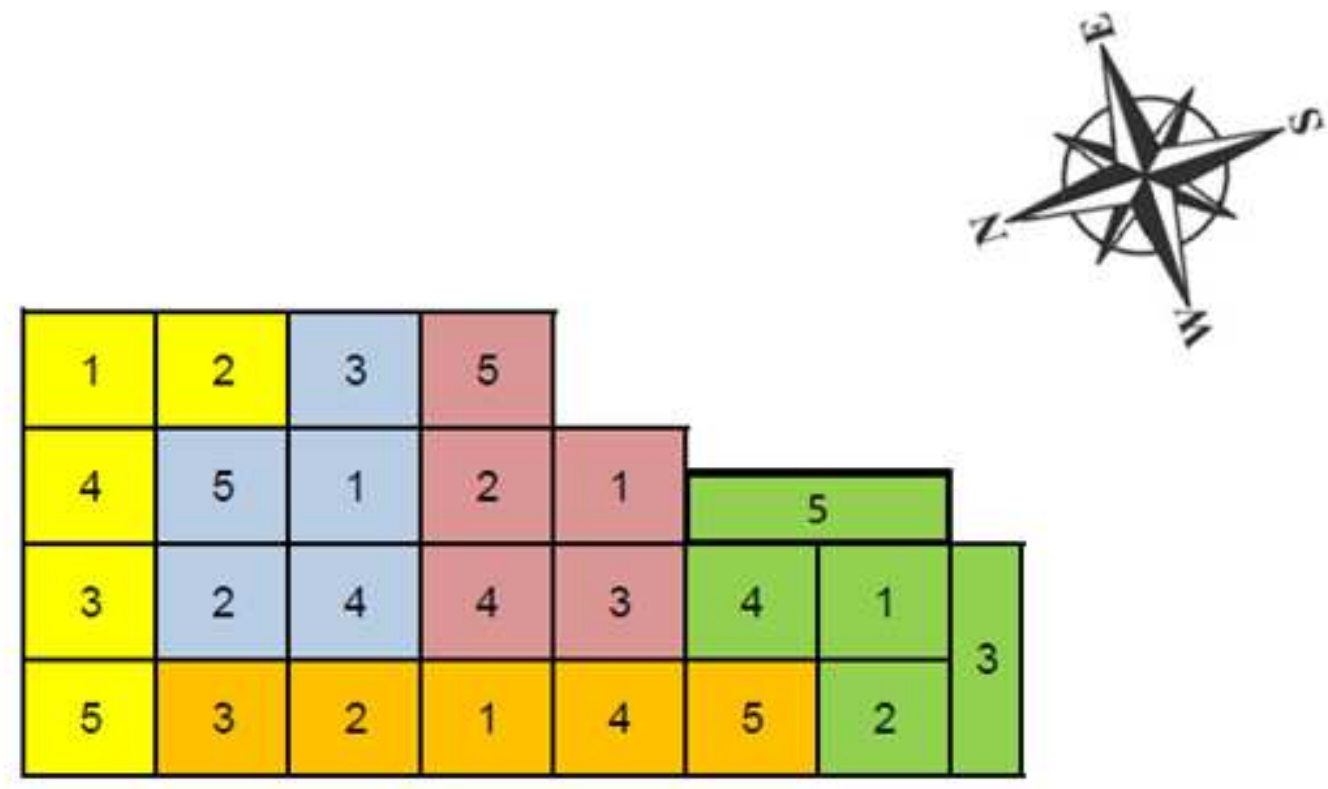

\section{Blocks:}

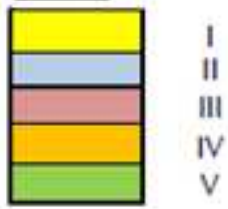

\section{Seedling production technologr.}

$1 \quad 3 / 0$ bare-root seedling, three years in the open nursery

$2 \quad 3 /$ Pin bare-root seedling, three years under the Pinus sylvestris (L.) canopy

3 3/Pic bare-root seedling, three years in opening in a Norway spruce (Picea ables Karst.) stand

$4 \quad 2 / 9$ bare-root seedling, two years under a shading net, a year in the open

$5 \quad 2 / \mathrm{K}$ ball-root seedling, two years under a shading net, a year in Kosterkiewicz ballot in the open

\section{Figure 1}

The layout of the experiment 


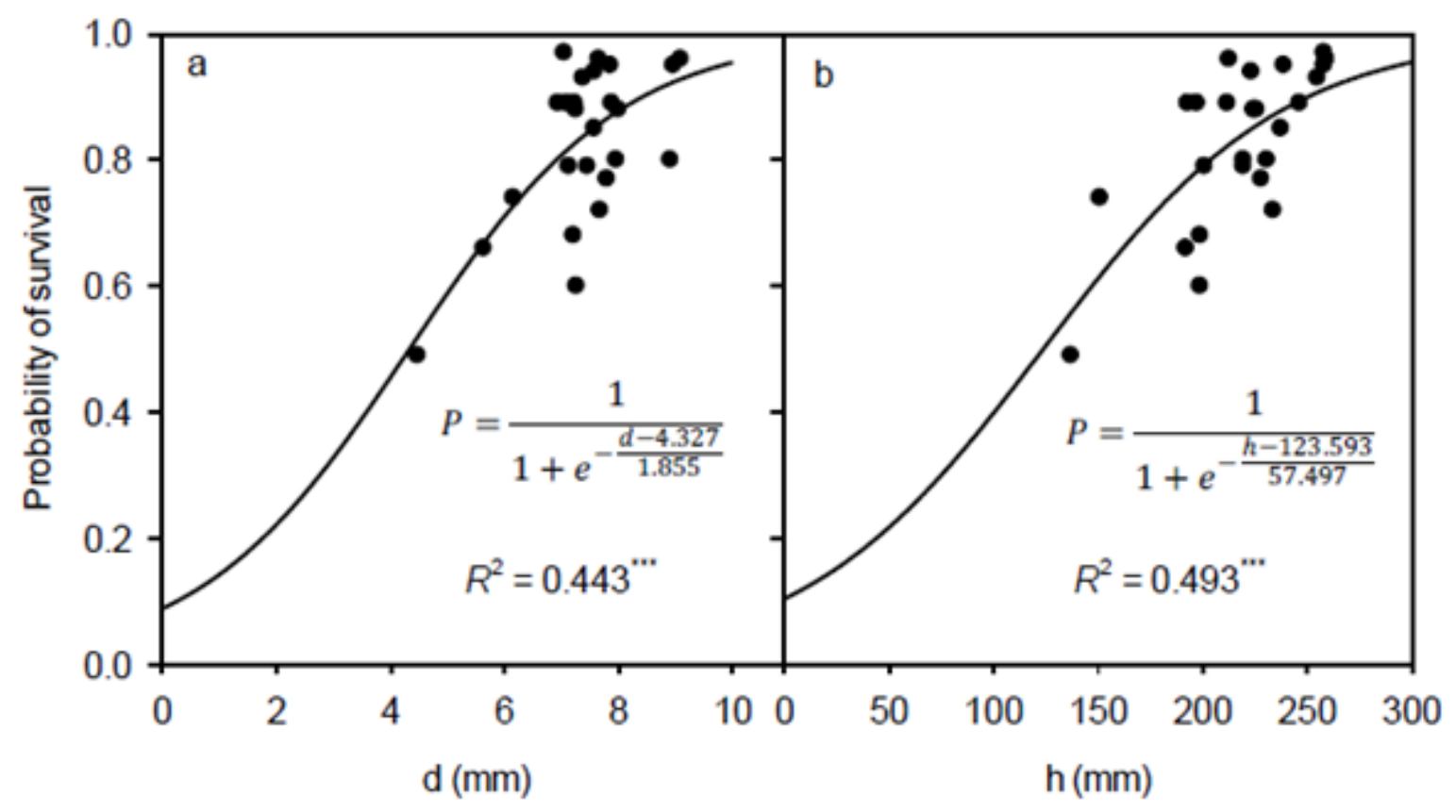

Figure 2

The logistic regressions: probability of survival vs. stem diameter at root collar (a), probability of survival vs. height (b). Silver fir seedlings were prepared with one of five technologies in forest nurseries. Each point represents the value of survival probability per seedling production technology per block. Equations of logistic regression, coefficients of determination (R2) with probability $(* * * P<0.001)$ are shown. $d-$ diameter at root collar; $\mathrm{h}$ - height 


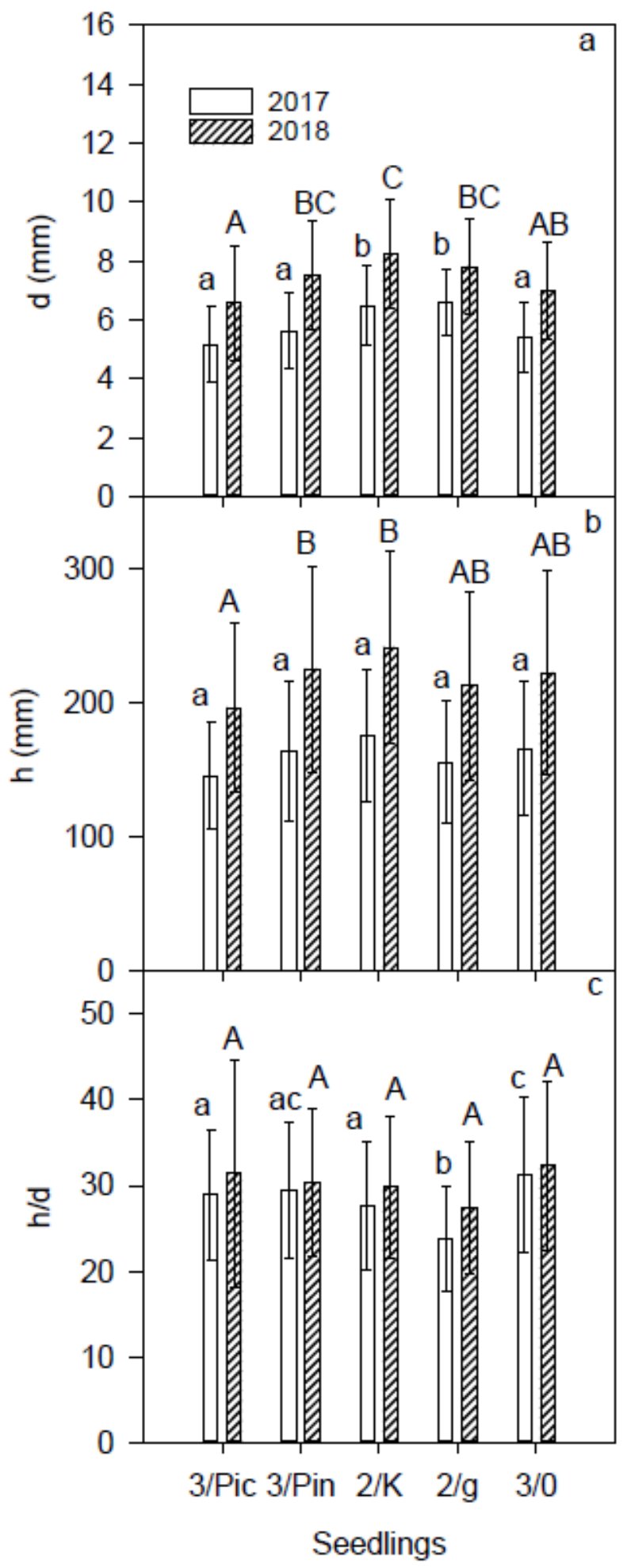

Figure 3

(a) Stem diameter at root collar (d), (b) height (h) and (c) degree of slenderness (h/d) (means \pm SD) of silver fir seedlings grown in forest nurseries using one of five technologies. The same letters (2017 small letters, 2018 - capital letters) above columns indicate that the mean values do not differ among the seedling production technologies in Duncan's post-hoc test at $a=0.05$ (in $2017 \mathrm{n}=2397$, in $2018 \mathrm{n}=$ 2050). 3/Pic - bare-root seedling, three years in an opening in a Picea abies stand; $3 /$ Pin - bare-root 
seedling, three years under a Pinus sylvestris canopy; $2 / \mathrm{K}$ - ball seedling, two years under a shading net, one year in Kosterkiewicz' ballot in the open; $2 / \mathrm{g}$ - bare-root seedling, two years under a shading net, a year in the open; $3 / 0$ - bare-root seedling, three years in an open nursery. For ANOVA results see Table 3

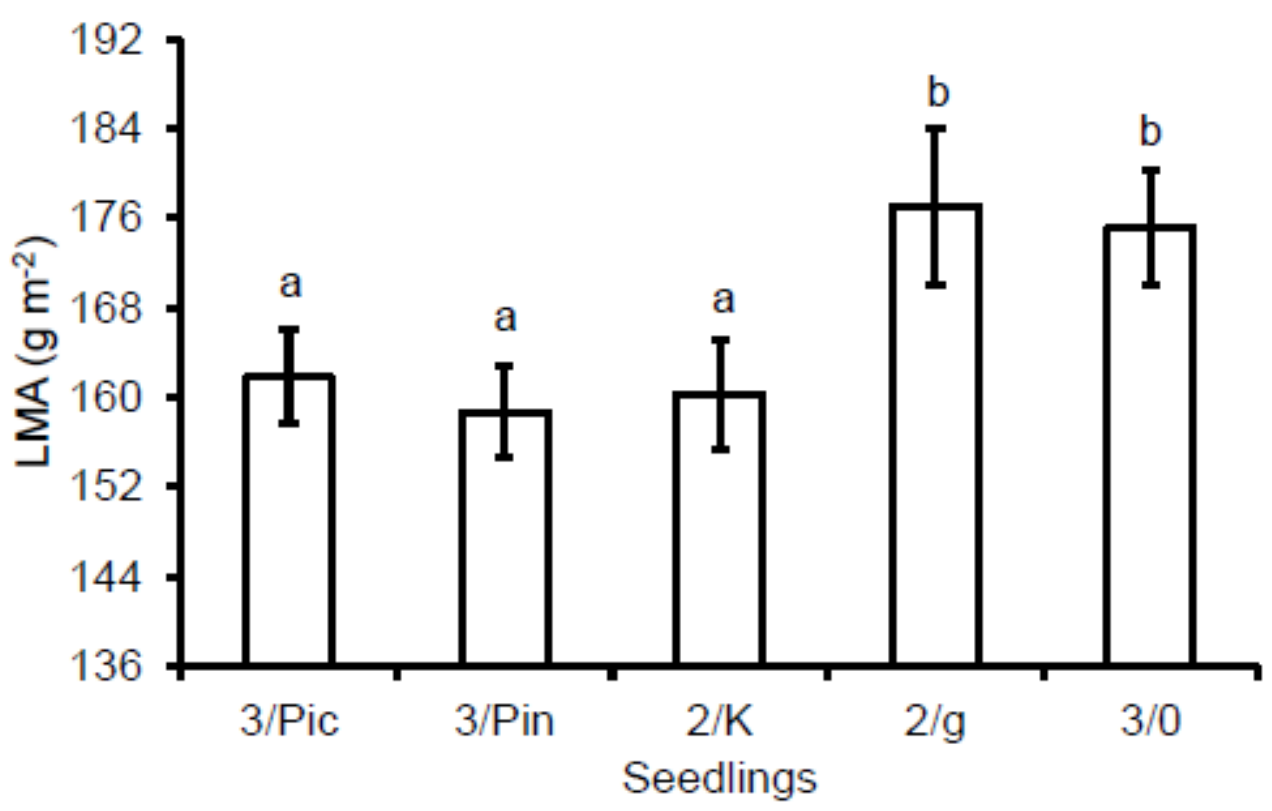

Figure 4

The leaf mass-to-area ratio (LMA, means $\pm S E$ ) of Abies alba seedlings prepared with one of five seedling production technologies in forest nurseries prior to planting. Needle samples were collected from seedlings in the second growing season, in August 2018. The same letters above columns indicate that the mean values do not differ among the methods of seedling production in Duncan's post-hoc test at $a=$ 0.05 ( $n=25, n-$ number of replicates per treatment). For abbreviations, see the caption of Fig 1 . 


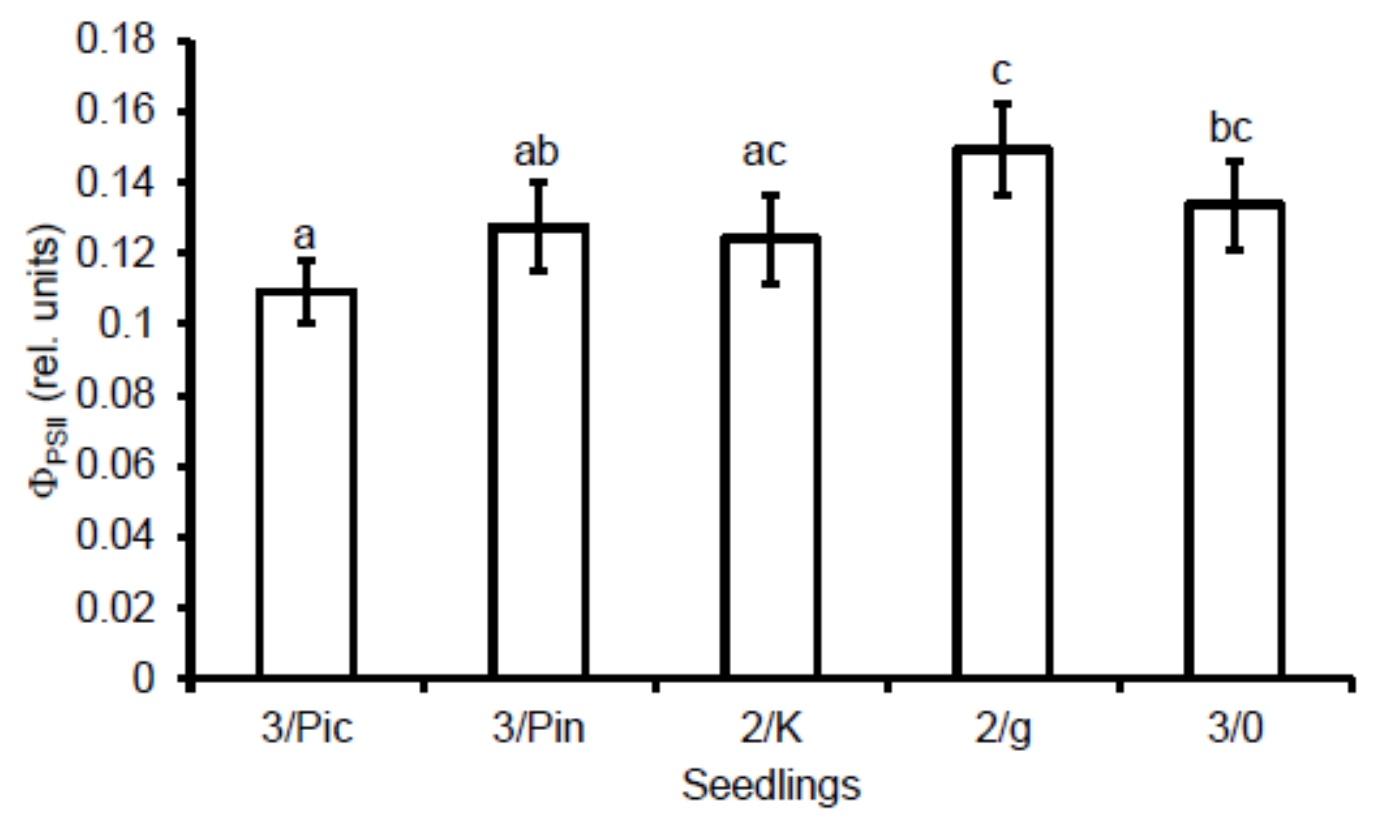

Figure 5

Quantum yield of PS II efficiency (ФPSIl, means \pm SE) measured in Abies alba needles illuminated a priori with actinic light (PPF $=350 \mu \mathrm{mol} \mathrm{m-2} \mathrm{s-1)} \mathrm{after} \mathrm{stabilization} \mathrm{of} \mathrm{steady} \mathrm{state} \mathrm{fluorescence} \mathrm{(Fs).} \mathrm{The} \mathrm{same}$ letters above columns indicate that the mean values do not differ among the seedling production technologies in Duncan's post-hoc test at $a=0.05(n=25)$. For abbreviations, see the caption of Fig 1 


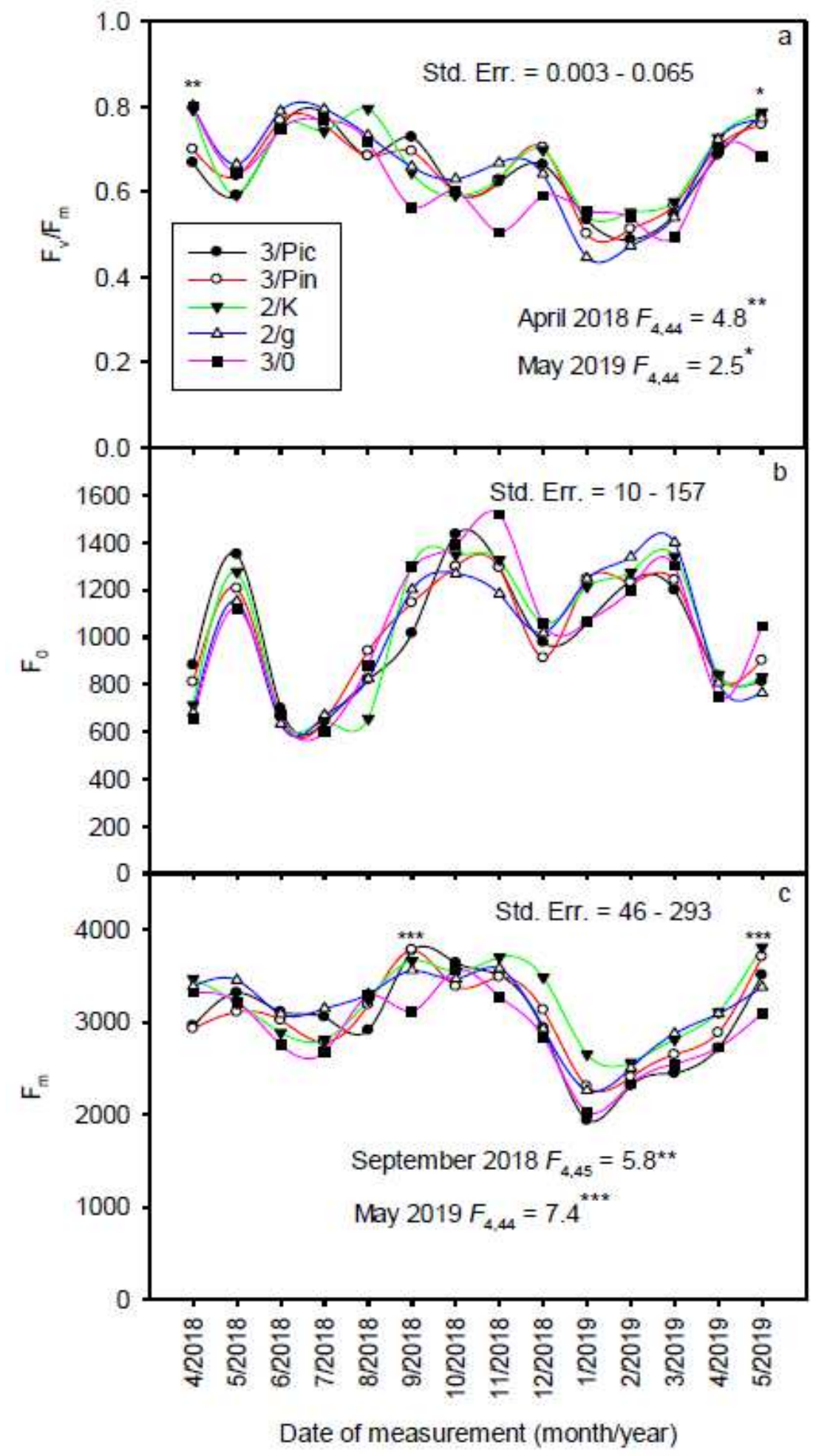

\section{Figure 6}

Time-course of maximum quantum yield of PSIl photochemistry (Fv/Fm), basic fluorescence yield (F0) and maximum fluorescence yield (Fm) monitored in needles of Abies alba seedlings grown in forest nurseries using one of five technologies during 3 years and planted in the open (means, $n=10$ ). Results of one-way ANOVA at $p \leq 0.05$ are shown. The significant differences among mean values in Duncan's test within the date of fluorescence measurements are marked with asterisks $(* \star * *<0.001)$ 